\title{
Supply chain finance, financial constraints and corporate performance: An explorative network analysis and future research agenda
}

\author{
Philipp Wetzel", Erik Hofmann \\ Institute of Supply Chain Management (ISCM-HSG), Supply Chain Finance-Lab (SCF-Lab), University of St. Gallen (HSG), Dufourstrasse 40a, CH-9000, St. Gallen, \\ Switzerland
}

\section{A R T I C L E I N F O}

\section{Keywords:}

Supply chain finance

Working capital assets

Financial constraints

Corporate performance

Secondary data

Network analysis

\begin{abstract}
A B S T R A C T
In this paper, we examine the functional form of the relationship between working capital assets and corporate performance beyond the traditional single-company perspective. In particular, we explore how a focal company's adequate level of working capital is influenced by the presence of limited financial resources along the supply chain. Moreover, we investigate the performance impact of supply chain finance (SCF)-oriented working capital management (WCM) approaches. Based on the SCF-oriented school of thought, we subject propositions regarding the relationship between working capital and corporate performance from prior WCM research to explorative empirical testing. In doing so, we raise awareness of factors that have yet to be tested. We derive methodological implications for conducting interorganizational studies in the field of SCF and outline a future research agenda. The explorative results indicate (i) the existence of a profit-maximizing level of working capital, (ii) superior performance of companies adopting an SCF-oriented WCM approach, (iii) higher profitmaximizing levels of working capital for focal companies facing financially constrained supply chain partners, (iv) a positive performance impact of efficient inventory management, and (v) differentiated payment strategies toward up- and downstream supply chain partners.
\end{abstract}

\section{Introduction}

Systems theory suggests that local management decisions aimed at maximizing the performance of a particular function in an organization may result in suboptimal outcomes that adversely affect the overall performance of a company (Drucker, 1962). Supply chain management (SCM) research expands this concept to include networks of companies, claiming that collaboration among firms leads to enhanced performance and improved competitive advantage (Randall and Farris, 2009). From this perspective, working capital management (WCM), which reflects the financing relationships between companies, presents a key opportunity for interorganizational optimization (Tsai, 2008; Bernabucci, 2008). This is the case because WCM can have a direct performance impact on affiliated supply chain partners (Hofmann and Kotzab, 2010). For example, if a powerful buyer company is stretching its accounts payable, related suppliers will find themselves confronted with higher accounts receivable levels, which have been found to negatively impact their overall performance (Autukaite and Molay, 2014; Jose et al., 1996). In the long run, higher accounts receivable levels may also have a negative performance impact on the buyer, because suppliers may respond with an increased unit price or reduced service level to compensate for the additional financing costs (Hofmann and Zumsteg, 2015). A progressive buying company may be aware of this and stretch its accounts payable using an innovative supply chain finance (SCF) instrument such as reverse factoring, lengthening its payment terms to suppliers while giving the latter the option to get paid early (Camerinelli, 2009; Wuttke et al., 2016). Due to these crosscompany interdependencies, WCM can have a direct performance impact on affiliated supply chain partners.

However, few studies have analyzed working capital assets (accounts receivable, accounts payable, and inventories) in an interorganizational supply chain setting (Farris and Hutchison, 2002; Randall and Farris, 2009; Hofmann and Kotzab, 2010). The vast majority of studies have applied a single-company perspective when analyzing the performance impact of WCM (e.g. Shin and Soenen, 1998; Wang, 2002; Deloof, 2003; Lazaridis and Tryfonidis, 2006; GarcíaTeruel and Martínez-Solano, 2007), neglecting the fact that self-centered management practices, such as systematic payment terms extensions, may adversely affect affiliated upstream supply chain partners (suppliers).

Against this background, the first goal of this study is to analyze the functional form of the relationship between working capital and

\footnotetext{
* Corresponding author

E-mail addresses: philipp.wetzel@unisg.ch (P. Wetzel), erik.hofmann@unisg.ch (E. Hofmann).
} 
corporate performance beyond the traditional single-company focus, extending the modeling perspective to the interorganizational supply chain network level. This is consistent with recent calls for more empirical research examining how working capital is optimally allocated in a supply chain network to improve operational performance (Gupta and Dutta, 2011; Protopappa-Sieke and Seifert, 2017). The focus of this study therefore lies outside the traditional scope of core WCM research and can yield valuable findings, enlarging the body of WCM to SCF research.

A second goal of this study is to analyze how the presence of financial constraints along the supply chain influences a focal company's performance-maximizing level of working capital. There is general agreement in SCM research that firms do not operate in isolation but are bound by the structure of the network in which they operate (Carnovale et al., 2019). Resource dependency theory posits not only that crosscompany collaboration leads to significant value creation but also that a company's extended network is a vital source for gaining access to informational, physical, and financial resources (Galaskiewicz, 2011). However, research on the relationship between (net) working capital and corporate performance has yet to consider how limited access to financial resources along the supply chain impacts a (focal) company's performance-maximizing level of working capital.

In this light, a third goal of the study is to analyze the performance effects of collaborative SCF approaches. Under such collaborative SCF approaches, we subsume all WCM practices that optimize financial flows at an interorganizational level, resulting for example in lower debt costs, reduced working capital within a supply chain network, or new financing opportunities for financially constrained companies (Gelsomino et al., 2016; Camerinelli, 2009; Randall and Farris, 2009). An example of a collaborative SCF approach is approved payables financing that allows a focal company to extend its days payable outstanding (DPO) and at the same time to shorten its supplier days sales outstanding (DSO) (Wuttke et al., 2013a). Currently, little is known about why collaborative SCF approaches are superior to a self-centered WCM approach (Viskari and Kärri, 2012). Against the background of these goals, we elaborate on the following research questions:

RQ1. What is the functional form of the relationship between working capital assets and corporate performance in a supply chain network context?

RQ2. In what way do limited financial resources of affiliated supply chain partners affect a focal company's performance-maximizing level of working capital?

RQ3. Do companies following an SCF-oriented WCM approach achieve superior financial performance?

Inspired by Serpa and Krishnan (2018), Kim and Henderson (2015), and Lanier et al. (2010), we link (focal) companies based on secondary data to their major customers and suppliers. However, in contrast to these studies, instead of relying on the Statement of Financial Accounting Standards (SFAS) No. 131's major customer disclosure to identify our supply chain networks, we rely on the SPLC data on Bloomberg, which offers detailed insights into a company's supply chain relationships. Beyond that, we gather financial data regarding a focal company's up- and downstream supply chain partners. Methodologically, we build on past WCM research and apply a quadratic model to estimate our parameters (Baños-Caballero et al., 2014; Afrifa, 2016; Afrifa and Padachi, 2016). However, due to the dynamic nature of supply chain networks, we do not employ a panel data regression, but rather a cross-sectional regression analysis.

By addressing these research questions, we contribute to current WCM and SCF literature in the following ways. First, we subject theoretical propositions from prior WCM research to explorative empirical testing and raise awareness of untested factors in the relationship between working capital and corporate performance. Second, responding to the call from Viskari and Kärri (2012); Busi and Bititci (2006);
Protopappa-Sieke and Seifert (2017), we examine the performance impacts of collaborative WCM approaches in an interorganizational supply chain network context. Third, by underpinning our theoretical claims with new evidence regarding the relationship between investment in working capital and corporate performance, we make a methodological contribution to the growing body of SCF research. Fourth, we test the impact of financial constraints along the supply chain on this relationship. In doing so, we further contribute to the SCM literature that analyzes cross-company relationships beyond the traditional buyer-supplier dyad (Håkansson and Persson, 2004; Wichmann and Kaufmann, 2016; Carter et al., 2015). Fifth, our study has important methodological implications for future interorganizational WCM research in the field of SCF.

The remainder of the paper is organized as follows. In section 2, we review previous research and derive five implications for our explorative supply chain network analysis. In section 3 , we describe the methodological approach and data used in our examination. In section 4 , we present our findings. Section 5 presents our discussion, which includes methodological suggestions for future SCF research. Section 6 concludes the paper and provides an outlook for future studies.

\section{Theoretical background}

\subsection{Current state of research}

In general, there are two opposing views of WCM. Researchers in one camp have applied a single-company perspective, focusing on the management of working capital of one corporate entity. This view is particularly widespread in the finance literature, and its authors have mainly addressed three issues. ${ }^{1}$ One group of scholars has analyzed the practices and strategies companies use to manage their working capital, mainly by means of large surveys and questionnaires (Belt and Smith, 1991; Khoury et al., 1999; Ricci and Morrison, 1996). A second group has analyzed the determinants of working capital, such as firm size or industry sector, and how they affect the working capital requirements of a company (Moss and Stine, 1993; Hill et al., 2010). A third group has analyzed the relationship between WCM and firm profitability, primarily by applying correlation and regression analyses (Jose et al., 1996; Shin and Soenen, 1998; Deloof, 2003; García-Teruel and Martínez-Solano, 2007). Studies analyzing the functional form of the relation between investment in working capital and corporate performance can be further grouped into three categories, which we define as the (i) traditional, (ii) alternative, and (iii) progressive WCM school of thought.

Departing from the dominant single-company perspective, researchers in the second camp have devoted more attention to the supply chain, sharing the assumption that the analysis and optimization of working capital must take place at the interorganizational level. As a result, this body of literature is situated at the intersection of the finance, logistics, and SCM literature and stresses the importance of considering up- and downstream supply chain partners when optimizing a company's working capital (Hofmann and Zumsteg, 2015; Huff and Rogers, 2015; More and Basu, 2013; Blackman et al., 2013; Wuttke et al., 2013b). This literature stream can be summarized with the term "supply chain finance" (SCF), and it emerged only recently, when scholars started to acknowledge the importance of financial flows along the supply chain (Gupta and Dutta, 2011; Raghavan and Mishra, 2011; Cavenaghi, 2013). However, although several authors have considered financial flows as one of the main pillars of SCM (Mentzer et al., 2001; Cooper et al., 1997), a consistent understanding of SCF is still lacking (Popa, 2013; Martin and Hofmann, 2019). In this paper, we focus on the eligible assets for SCF of a focal company's supply chain network. We

\footnotetext{
${ }^{1}$ The classical literature on working capital has its origin in the finance literature (Smith, 1973; Gentry et al., 1990).
} 


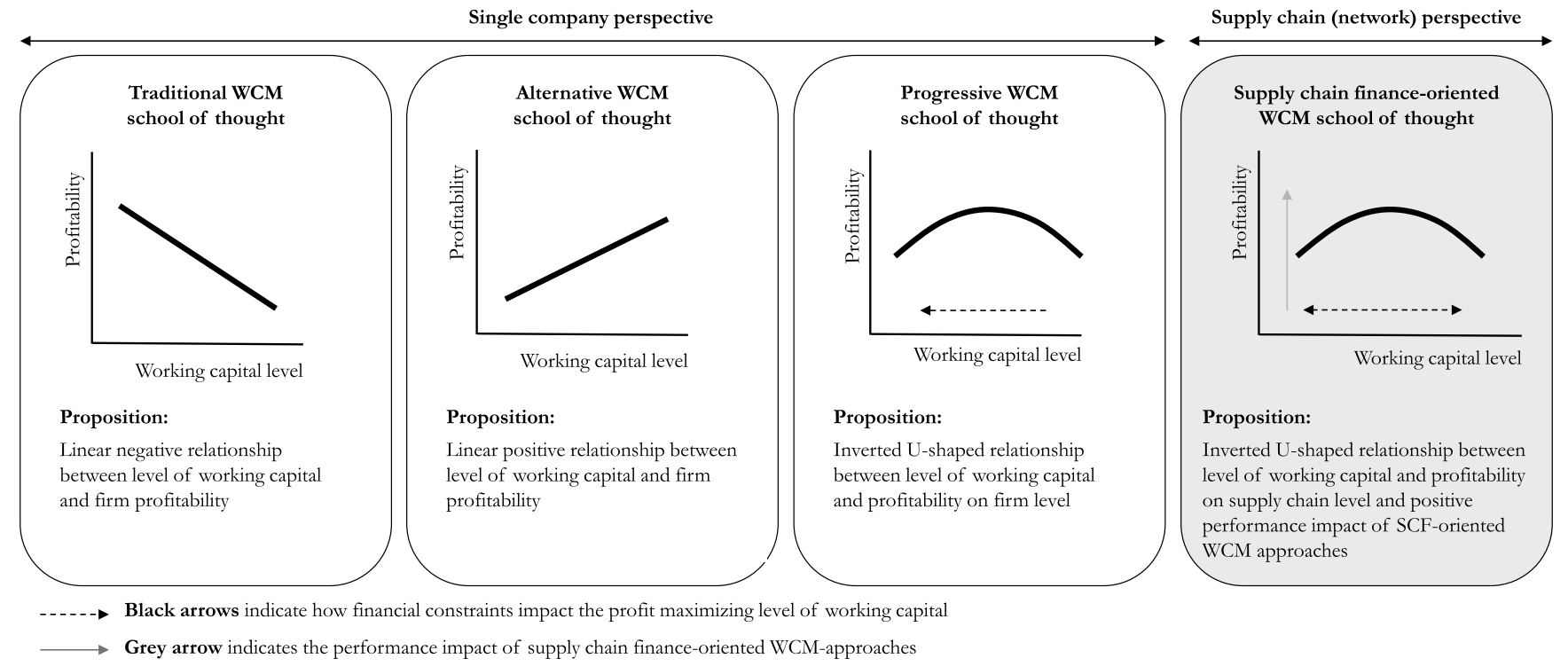

Fig. 1. Relationship between investment in working capital assets and corporate performance according to different schools of thought.

therefore follow the definition of Pfohl and Gomm (2009) and Wuttke et al. (2013b), who broadly define SCF as the interorganizational optimization of working capital financing between companies to increase the value of all participating actors.

In this light, our study is not only positioned at the intersection of the corporate finance, SCF, SCM, and logistics literature but also makes use of theoretical concepts from the trade credit literature (Emery, 1984; Wilner, 2000; Cunat, 2007). As such, our paper investigates working capital assets through the lenses of different strands of literature, and by doing so, it bridges gaps between these areas of research.

\subsection{Traditional WCM school of thought}

The traditional theory proposes that there is a linear negative relationship between the level of working capital and firm profitability (Shin and Soenen, 1998; Singh et al., 2017). This theory is illustrated in the first box of Fig. 1. It is the most widespread theory and has been supported by numerous studies. For example, in a sample of 2718 firms, Jose et al. (1996) found a negative relationship between WCM and the CCC using return on assets (ROA) and return on equity (ROE) as profitability measures. A comparable result was obtained by Deloof (2003) in a sample of 1009 firms using gross operating profit (GOP) and net operating profit (NOP) as profitability measures. Similarly, Wang (2002) found a negative association between WCM and the CCC of firms operating in Japan and Taiwan. Lazaridis and Tryfonidis (2006) provided further support for the argument with a sample of 131 firms listed on the Athens Stock Exchange.

There are several theoretical explanations for these results. For example, lower working capital levels result in lower financing and interest costs (Brandenburg, 2016; Bian et al., 2018). In addition, firms may be forced to draw capital away from alternative value-enhancing projects if they have too much capital tied up in working capital positions (opportunity costs) (Deloof, 2003; Baños-Caballero et al., 2014). This traditional view of WCM has received further support from the studies of García-Teruel and Martínez-Solano (2007), Autukaite and Molay (2014), Zeidan and Shapir (2017) and Chang (2018).

\subsection{Alternative WCM school of thought}

The alternative school of thought represents a transition from the traditional school of thought, proposing a positive linear relationship between the level of working capital and corporate performance (see the second box in Fig. 1). Higher investment in working capital is thought to increase a firm's profitability (Sharma \& Kumar, 2011; Tauringana and Afrifa, 2013; Afrifa and Padachi, 2016). Various papers have supported this view. For example, Gill et al. (2010) analyzed manufacturing firms listed on the New York Stock Exchange and found a positive association between the CCC and firm profitability. These research results were substantiated by the findings of Alarussi and Alhaderi (2018), who find a strong positive relationship between working capital, firm size, company efficiency and profitability.

There are multiple theoretical explanations for a positive relationship between working capital and corporate performance. For example, larger inventories reduce the risk of price fluctuations, distortions in the production process, and of out-of-stock situations, which are costly because they limit a firm's sales opportunities (Blinder and Maccini, 1991; Eroglu and Hofer, 2011). Granting credit in the form of extended payment terms can serve as a price cut, increase a firm's sales at times of low demand, or strengthen a firm's long-term relationships with customers and suppliers (Emery, 1984; Petersen \& Rajan, 1997; Shah, 2009). Shipley and Davies (1991), Deloof and Jegers (1996) and Blazenko and Vandezande (2003) demonstrated that supplier credit can serve as an important unique selling proposition when there is low product differentiation in the market. Analogously, Wilner (2000) and $\mathrm{Ng}$ et al. (1999) demonstrated that a firm can obtain significant price discounts by accepting low (own) DPO values, which exerts a positive effect on a firm's total costs. In addition, Carpenter et al. (1994) demonstrated that adjustment costs for fixed assets are in general higher than those for working capital. Accordingly, it is less expensive for high-working-capital firms to counterbalance a potential short-term liquidity shock. This is especially true for financially constrained firms. In this sense, working capital may also serve as a stock of precautionary liquidity (Fazzari and Petersen, 1993).

\subsection{Progressive WCM school of thought}

The traditional and alternative schools of thought of WCM maintain that both high and low levels of working capital may be justified (Tauringana and Afrifa, 2013; Deloof, 2003; Pike and Neale, 2003; Niskanen and Niskanen, 2006). Based on this insight, the progressive school of thought, illustrated in box three of Fig. 1, arose, emphasizing the view already proposed by Rafuse (1996): working capital is an 
investment to keep a business running, and each firm has to manage a trade-off between too much capital tied up (e.g. avoiding high inventory costs) and too little working capital available for its operational daily business (e.g. avoiding risk foregone sales).

In the recent literature, a few papers have highlighted this trade-off (Eroglu and Hofer, 2011; Mun and Jang, 2015; Afrifa and Padachi, 2016; Altaf and Shah, 2017). For example, Baños-Caballero et al. (2014) examined, in a sample of nonfinancial UK companies, the association between WCM and firm profitability and found an inverted Ushaped relationship, arguing that financially constrained firms have lower optimal working capital levels. Singhania and Mehta (2017) analyzed the impact of WCM on corporate performance in 11 economies of the Asia Pacific region and found that both excessive working capital and a shortage of working capital can impair the profitability and health of a company. Soykan and Ulucak (2016) obtained similar results for a sample of nonfinancial firms quoted in Borsa Istanbul for the period 2004-2009, concluding that companies should strive to possess close to the optimal level of working capital.

\subsection{Supply chain finance-oriented WCM school of thought}

The SCF-oriented school of thought developed from the progressive school, and it takes into account that the management of working capital directly influences affiliated supply chain partners. In particular, it recognizes that accounts payable, inventories, and accounts receivable mirror the cross-organizational financing relationships of a focal company within a supply chain network. Fig. 2 captures this insight and illustrates that self-centered working capital improvements are made at the expense of affiliated supply chain partners.

Against this background, it becomes evident that studies belonging to the traditional, alternative, and progressive schools of thought of WCM have limitations. In particular, by restricting their perspective to single companies, they fail to analyze working capital in the necessary interorganizational context. SCF-oriented research, advancing the perspective toward the network context, has only recently been conducted by individual authors, such as Grosse-Ruyken et al. (2011) and Hofmann and Kotzab (2010). Similarly, researchers have only recently started to view the supply chain as an integrated entity and to develop the concept of supply chain orientation (Mello and Stank, 2005; Hult et al., 2008; Lee and Nam, 2016). From a theoretical modeling point of view, a few scholars have taken into account that companies are part of a network and have been conducted in the setting of dyadic or triadic relationships. For example, Randall and Farris (2009) used a case-based approach to demonstrate that collaborative WCM in dyadic supply chain relationships creates valuable opportunities to increase corporate performance. Viskari and Kärri (2012) identified five scenarios for how collaborative WCM can be used for value creation. Similarly, Hofmann \& Kotzab (2010) introduced a supply chain-oriented WCM approach, highlighting the optimization possibilities related to differences in the weighted average cost of capital (WACC) between trading partners. Farris and Hutchison (2002) and Grosse-Ruyken et al. (2011) demonstrated that CCC reduction opportunities exist outside a company's boundaries through collaboration with tier 1 and tier 2 suppliers. Monto (2013) found that collaborative management approaches can decrease the financing costs of working capital on the value chain level. Similarly, Miia (2014) showed that the average level of working capital is higher in the upstream supply chain companies than in the downstream companies. This is in line with the findings of Seifert (2010), who found that the more accounts payable and receivable increase, the further upstream a company is positioned in the supply chain.

\subsection{Indications of previous research}

\subsubsection{Indication 1}

The progressive school of thought of WCM, which expands on the traditional and alternative school of thought, suggests an inverted Ushaped relationship between the level of working capital and corporate performance. It is reasonable to assume that this assumption is especially true in a supply chain network context, when the working capital assets and financial wealth of a focal company's up- and downstream partners are taken into consideration. The SCF-oriented school of thought maintains that systematic payment term extensions against suppliers lead to upstream supply chain disruptions or cause negative distortions (Boissay and Gropp, 2007). Thus, it is vital that the conflicting interests between affiliated supply chain members are well managed and that the resulting costs and benefits are split up appropriately (Hofmann and Kotzab, 2010; Lamptey et al., 2017). Against this background, we expect: There exists a profit-maximizing level of working capital for focal companies.

\subsubsection{Indication 2}

Continuing with the idea of a profit-maximizing level of working capital, it is reasonable to assume that a balanced CCC, meaning that affiliated supply chain partners have similar CCC lengths, along the supply chain is superior to an unbalanced one. Grosse-Ruyken et al. (2011) already took up this idea by showing that WCM approaches that squeeze upstream and downstream companies may weaken the extended value stream and that an adequate CCC, which lies in the band of strategic CCC, pays off. We capture this idea with the concept of supply chain orientation, which we define as the recognition by an

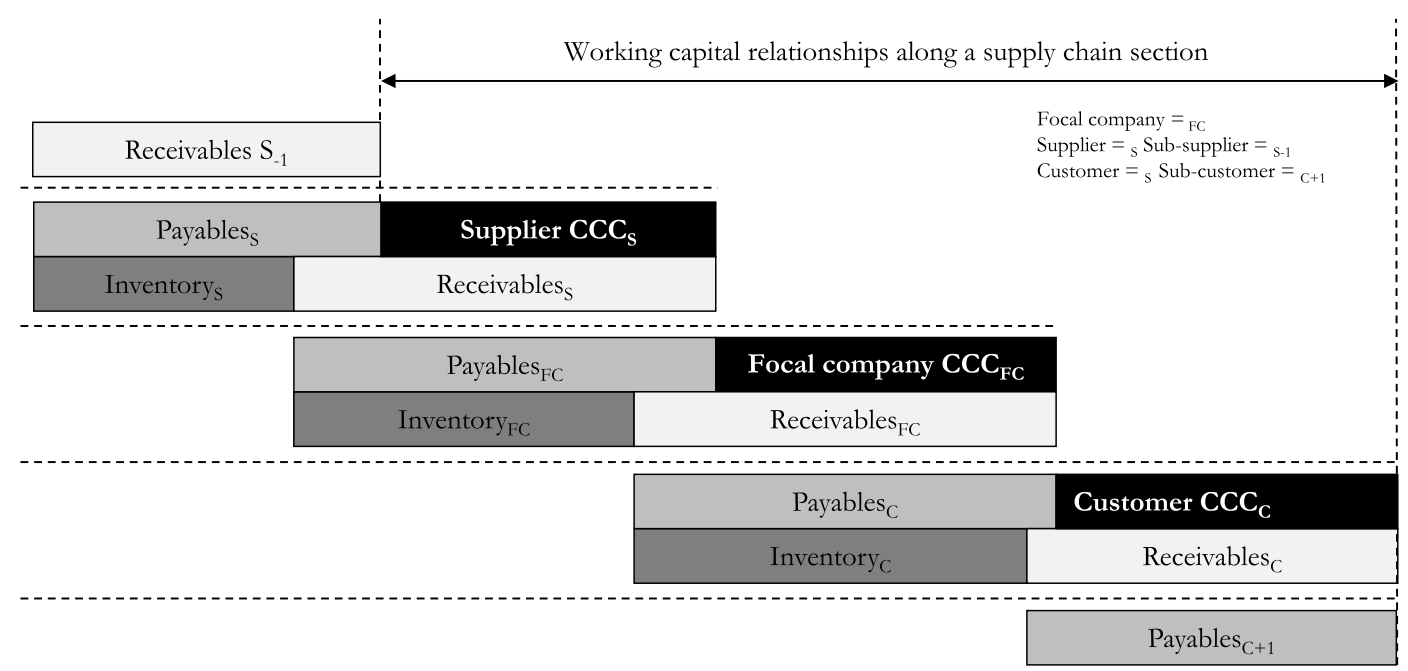

Fig. 2. Supply chain finance-oriented perspective on working capital assets. 
organization of the systemic strategic implications of the tactical activities involved in managing the various flows in a supply chain (Mentzer et al., 2001, p.11). Monto (2013) convincingly argued that collaborative WCM practices increase profitability on the value chain level. Similarly, Blackman et al. (2013), who analyzed the financial supply chain strategy of Motorola, highlighted how a collaborative approach can lead to a significant reduction in the cost of financing. Chandra \& Kumar (2000) went even further, proposing that a company can be successful only if the entire supply chain in which it acts is successful as well. The results of that study have two implications. First, companies should consider the tied-up working capital of their supply chain partners when optimizing their own working capital (GrosseRuyken et al., 2011). Second, a reduction in a company's CCC is advisable only when there are no adverse side effects for the supply chain partners (Chandra \& Kumar, 2000). Therefore, we expect: Collaborative SCF-oriented WCM approaches have a positive impact on corporate performance.

\subsubsection{Indication 3}

Various studies have suggested that the optimal level of working capital of financially constrained firms is lower than that of financially unconstrained firms (Baños-Caballero et al., 2014; Afrifa, 2016; Fazzari and Petersen, 1993; Chiou et al., 2006; Hill et al., 2010). By implication, the same logic can be expanded analogously to financially strong focal companies facing financially constrained supply chain partners. By accepting a higher working capital level, they can, for example, shorten their payment terms, which benefits their financially constrained suppliers (Hill et al., 2010). A supplier in financial distress can take advantage of a credit-granting customer, especially if it generates a large percentage of the customer's procurement costs. Analogously, the customer itself has an interest in maintaining the enduring productmarket relationship, because it reduces the likelihood of supply chain disruptions due to supplier insolvency. Against this background, we expect that it will be beneficial for focal companies to grant credit (in the form of increased payment speed toward suppliers or late payment opportunities for customers, respectively) to financially constrained supply chain partners. In particular, we assume that: Focal companies facing financially constrained supply chain partners have higher profitmaximizing levels of working capital than do those focal companies facing supply chain partners that are less likely to be financially constrained.

\subsubsection{Indication 4}

Prior studies have demonstrated that efficient supply chain material flows and reduced inventory levels are essential to reducing costs and enhancing operational performance. For example, Deloof (2003), in a sample of 1009 Belgian firms, found a significant negative relationship between the gross operating income and inventory levels. Likewise, García-Teruel and Martínez-Solano (2007) found a significant negative relation between ROA and inventory for a sample data of 8872 companies in Spain. ${ }^{2}$ It follows that companies should seek ways to reduce inventory levels, such as implementing balanced vendor-managed inventory concepts (Axsater and Rosling, 1993; Pohlen and Goldsby, 2003). Efficient inventory management correlates strongly with the financial performance of a company and is essential to reducing costs and capital tied up in supply chains (D'Avanzo et al., 2003; Greer and Theuri, 2012; Randall and Farris, 2009). We therefore expect: There exists a negative relationship between inventory levels within a supply chain network and a focal company's performance.

\footnotetext{
${ }^{2}$ The results of some studies are inconsistent with the findings of Deloof (2003) and García-Teruel and Martínez-Solano (2007). For example, Mathuva (2010) discovered a positive relationship between corporate performance and days inventory held (DIH), arguing that high inventory levels reduce the cost of possible interruptions in the production process.
}

\subsubsection{Indication 5}

In addition to the efficient management of goods and material flows, the efficient management of company-wide financial flows is essential to enhancing corporate performance. Protopappa-Sieke and Seifert (2017), for instance, examined strategic payment delays and identified a "double-marginalization effect," stating that strategically delaying downstream customers' payments results in higher supply chain costs and negatively impacts upstream suppliers. Miia (2014) analyzed the cycle times of WCM in the supply chain context and found that the average level of working capital is higher in the upstream supply chain companies than in the downstream companies. Likewise, Seifert (2010) discovered that the accounts payable and receivable increase the further upstream a company is positioned in the supply chain. These results correspond to the findings of Lorentz et al. (2016), who stated that the smaller and the further up the value chain a company is, the more it should be prepared to bear the burden of trade credit. ${ }^{3}$ It follows that when a focal company decides on payment terms for goods and services, the specific supply chain position of the respective partner should be taken into account in order to counterbalance potential variations in working capital requirements (Bian et al., 2018). Our last proposition therefore reads as follows: Differentiated (payment terms) strategies toward down-and upstream supply chain partners have a positive impact on a focal company's performance.

\section{Explorative network analysis}

\subsection{Toward a supply chain finance-oriented network analysis}

Analyzing cross-company financing relationships on the network level in supply chains based on secondary data is a complex task. For example, the perspective of public financial secondary data is generally applied at the firm level, whereas the relevant units of analysis of SCF research are cross-company relationships. Thus, we have to collect data from several stages in a supply chain that was not collected specifically to answer interorganizational research questions. By definition, this leads to many methodological challenges. For example, company networks usually lack a natural boundary (Wichmann and Kaufmann, 2016; Laumann et al., 1983). Both the horizontal network boundary (how many supply chain stages should be included?) and the vertical boundary (how many companies per supply chain stage should be included?) have to be carefully specified and constructed.

Another challenge is that even from a single-company perspective, it can be difficult to assign firms unequivocally to a single industry. For example, the firm 3M manages its operations in five highly different business segments, ranging from industrial, safety, and graphics to consumer electronics, energy, and health (see Fig. 3). The diversified organizational structure is reflected in the SIC codes that are assigned to the company. On the supply chain network level, a single-industry focus is even more challenging, arguably even misleading, because it does not adequately represent reality. In the case of $3 \mathrm{M}$, even the key up- and downstream supply chain partners ( $\mathrm{s}=$ suppliers and $\mathrm{c}=$ customers) belong to very different industries. In addition, many of these companies are themselves broadly diversified. Hence, a more focused sample may generally be preferable on the firm level (in the best case, on the business-unit level), whereas on the network level, this sampling strategy is not expedient. Nevertheless, it might be useful to select supply chain networks with focal firms belonging to a certain industry (e.g. manufacturing, consumer staples, or telecommunication).

\footnotetext{
${ }^{3}$ In this context, Randall and Farris (2009) as well as Gaski and Ray (2004) stated that suboptimal opportunistic actions, such as payment delays, can negatively impact the affiliated companies in a supply chain, suggesting that firms may achieve superior financial performance by collaboratively managing their working capital components.
} 


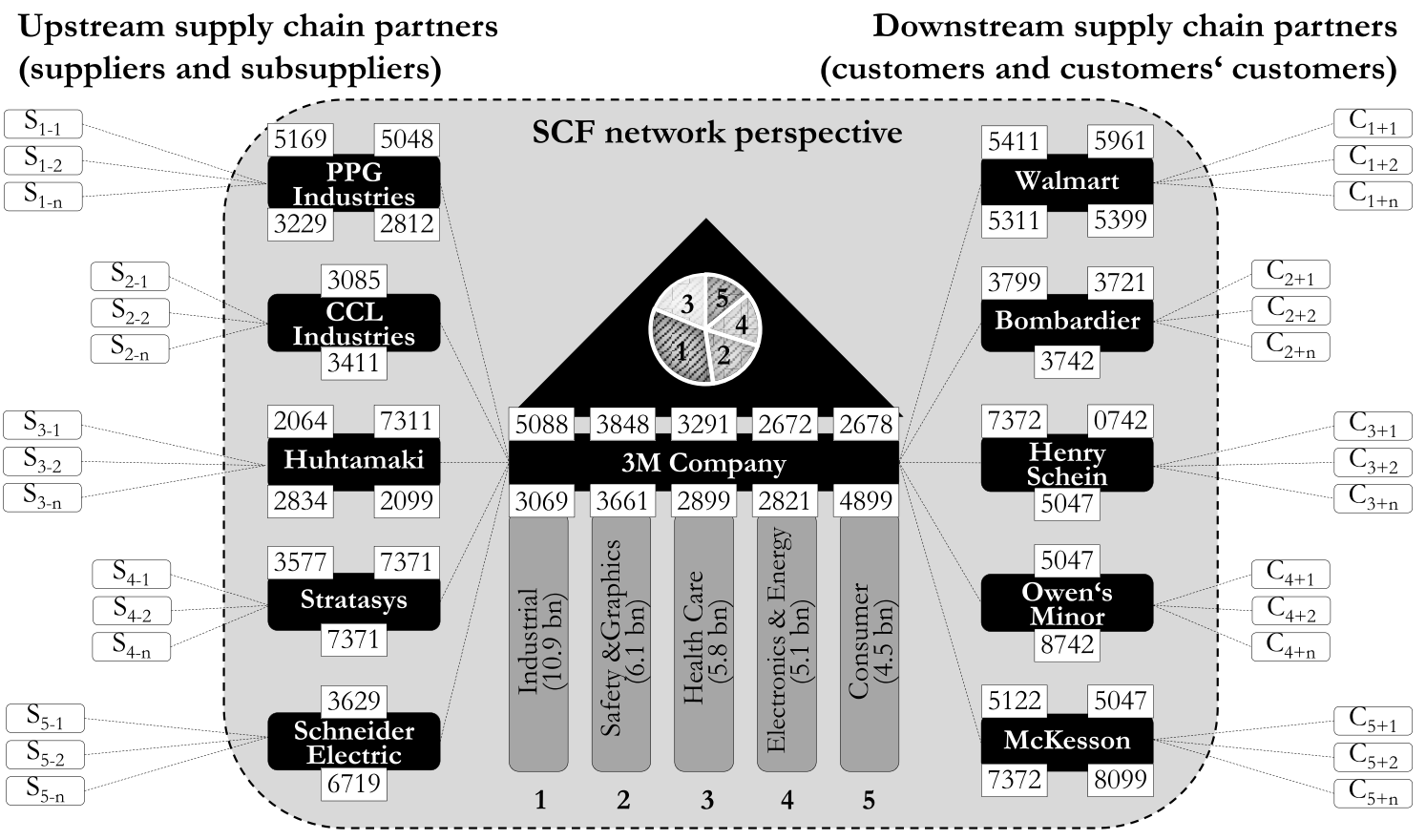

Note: Four-digit numbers indicate selected industry affiliations of $3 \mathrm{M}$ and its top suppliers (s) and customers (c); values in brackets indicate 3M's sales per business segment for the year 2017

Fig. 3. Extended supply chain network of the $3 \mathrm{M}$ company, including selected industry affiliations.

\subsection{Data collection}

We identified our supply chain networks by exploiting the SPLC data on the Bloomberg Terminal, which offers detailed insights into a company's supply chain relationships. Bloomberg uses a complex algorithm that assigns quantified values to supply chain relationships for which no quantification is publicly known. This is particularly advantageous for studying the relationship between working capital assets and corporate performance in the interorganizational context, because mandated supply chain disclosure requirements among public companies are in general very low. ${ }^{4}$

Within the framework of this paper, we focus on a focal company's working capital and its direct intertwining relationships between its five most important suppliers and customers. There are several reasons for determining the network boundaries in this way. First, Bloomberg in general does not reveal relationship data for more than a handful customers or suppliers. Second, the relevance of the listed customers and suppliers in terms of the relationship amount drops sharply - they quickly only represent a few percentage points of the procurement and sales volume, respectively. Third, limiting the analysis to the five most important suppliers and customers can at least partly reduce the complexity of the analysis. In this context, it can also be argued that today's firms tend to source most of their procurement volume from a few selected and strategic suppliers (Håkansson et al., 2010; Varadarajan et al., 2001). Fourth, because we use weighted averages in our method, there is a strong decreasing marginal utility of every additionally included supplier or customer. In this light, we are convinced that these limitations do not detract from the value of our analysis.

To ensure that our networks contain the companies to which a focal

\footnotetext{
${ }^{4}$ As a rather rare example, the Statement of Financial Accounting Standards (SFAS) No. 131 in the United States stipulates that firms have to identify any customer accounting for more than $10 \%$ of their total sales. Authors such as Lanier et al. (2010) and Kim and Henderson (2015) have used this source of data to form their triadic relationships.
}

company is most exposed, we sorted suppliers in descending order according the costs of goods sold (COGS) that get incurred at a focal company. In this process, we explicitly omitted suppliers listed with selling, general, and administrative expenses (SG\&A) and suppliers listed with capital expenditure (CapEx). This choice aimed to exclude all costs that are not directly related to the manufacturing process of a product and to obtain company networks that accurately represent the actual flow of goods along a supply chain network. Analogously, we sorted customers according the percentage of sales that they account for at the respective focal company. Consequently, each of our networks comprises five suppliers, five customers, and a focal company. For each company assigned to a network, we then collected accounting data from the annual Bloomberg data.

\subsection{Sample selection}

The sample selection process for this study consisted of three main steps. In the first step, we took a random sample of producing focal companies that (i) have manufacturing partnerships with suppliers and customers, (ii) have an industry revenue assigned by BICS larger than one hundred million from the manufacturing, consumer staples, and telecommunication sector, and (iii) are financially unconstrained. Following previous studies, we sample large positive dividend paying focal companies, assuming that the latter are unlikely to face financial constraints or bankruptcy risks (Baños-Caballero et al., 2014; Fazzari et al., 1988). The reasons for choosing multiple industries are as follows. In general, large listed companies are highly diversified and operate in various industries (see the example in Fig. 3). Thus, it is very difficult to assign company networks consisting of suppliers, focal companies, and customers to a single-industry sector. Fig. 4 illustrates that even the industry affiliation of a focal company's (single) most important customer - in terms of sales volume - varies greatly, not only between but also within the sampled focal company's industries. As illustrated in Fig. 5, the same pattern is evident with respect to a focal company's (single) most important supplier. Thus, unexpectedly, the 


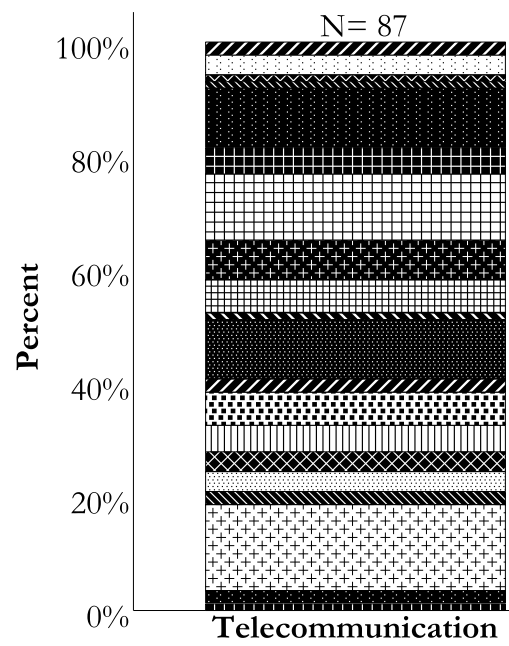

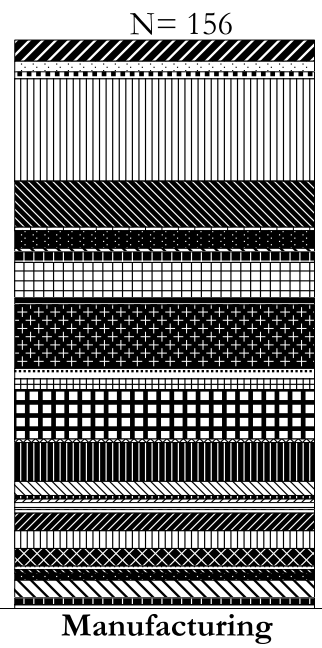

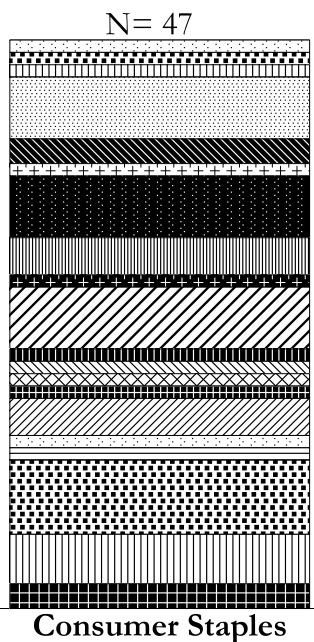

Top customer industry affiliation

\begin{tabular}{|c|c|}
\hline 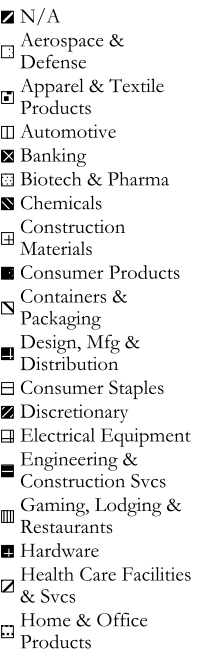 & 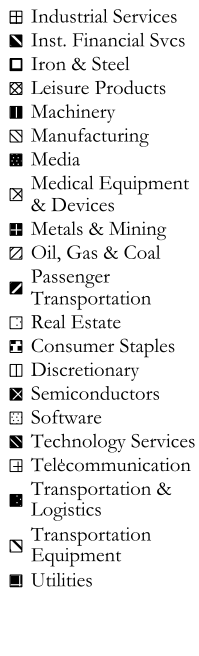 \\
\hline
\end{tabular}

Fig. 4. Industry affiliation of the (single) most important customer in terms of sales volume across the sampled focal company networks in Model 1.
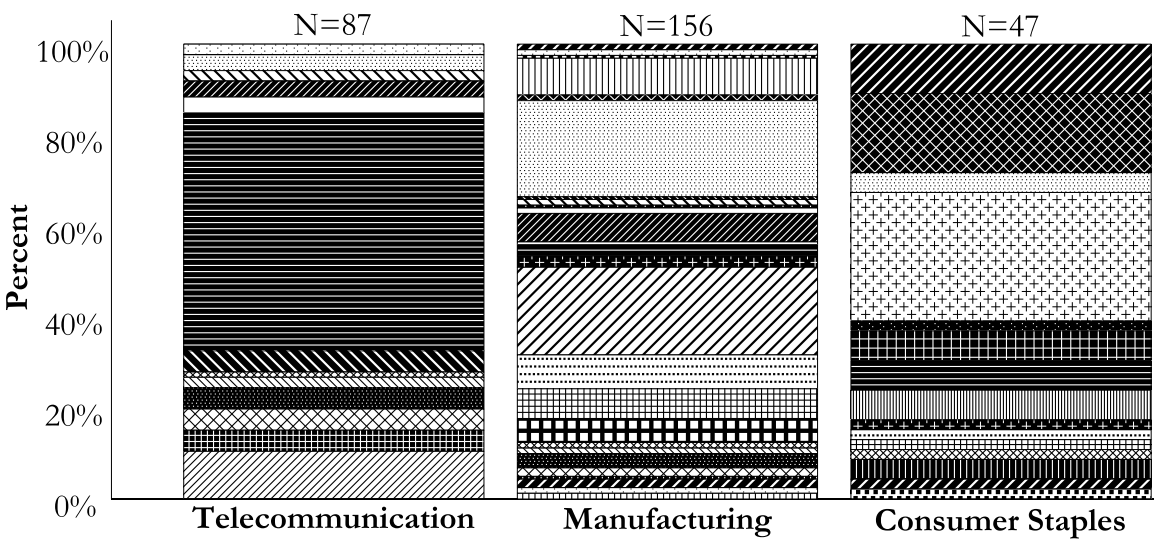

Top supplierindustry affiliation

Focal company industry affiliation

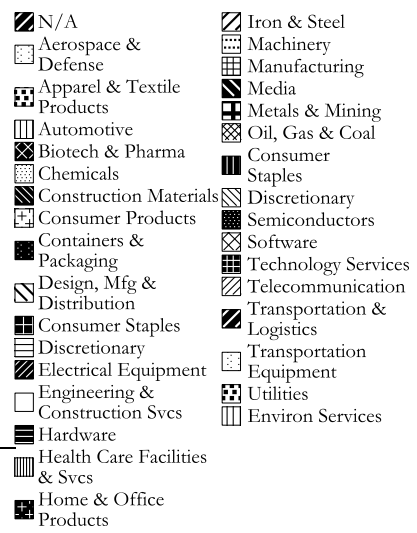

Fig. 5. Industry affiliation of the (single) most important supplier in terms of procurement volume across the sampled focal company networks in Model 1.

most important up- and downstream supply chain partners that are most intertwined with a focal company belong to very different industries. Due to this inevitable overlap, it can be assumed that the influence of industry-specific effects are weaker and even negligible on the network level. This assumption is further supported by previous studies that have concluded that industry-specific effects do not play a significant role - in some cases, even from a single-company perspective (Hill et al., 2010; Chiou et al., 2006). Beyond that, choosing multiple industries positively affects the sample size, because the exhaustiveness of relationship data for a single industry on Bloomberg rapidly decreases for smaller companies.

In the second step, we determined the major customers and suppliers - in terms of procurement and sales volume, respectively - of the respective focal company. In the third step, we systematically cleaned our data. A focal company and its supply chain partners were included in the analysis only if they were not missing data on any variable in the analysis (listwise deletion). There are two main reasons for applying such a strict selection procedure. First, the listwise deletion did not adversely affect the statistical power of our models, because the sample size was large enough. Second, our missing data diagnosis showed that the incomplete networks that were dropped did not systematically differ from the complete networks included in the analysis. Therefore, our analysis is unlikely to be influenced by nonrandom deletion issues.
In addition, to reduce the potential bias caused by outliers, we winsorized our variables at $0.5 \%$ and $99.5 \%$ and examined the data for influential outliers by calculating Cook's distance, including standardized residuals (Cohen et al., 2011).

As Fig. 6 shows, we analyze three different models with cross-section data from the year 2016 in total. With Model 1, we examine the functional form of working capital assets and corporate performance on the overall supply chain network level. With Model 2a, we deepen the analysis and focus on the upstream supply chain partners (suppliers). In particular, we test whether a focal company's performance-maximizing level of working capital changes when it faces suppliers with limited financial resources. With Model $2 b$, we analogously examine the performance impact of financially constrained customers.

Because each model consists of different variables, the sample size varies slightly across the models. Table 1 provides an overview of the supply chain networks in the sample. The initial sample for Model 1 consists of 2137 companies, of which 871 represent customers, 973 represent suppliers, and 293 represent focal companies. Through listwise deletion of companies that have one or more missing values, we get 290 networks, of which 71 are complete networks, consisting of 5 suppliers, 5 customers, and 1 focal company ( 11 companies in total). Of the latter, 54 percent belong to the manufacturing sector, 30 percent to the telecommunication sector, and 16 percent to the consumer staples 

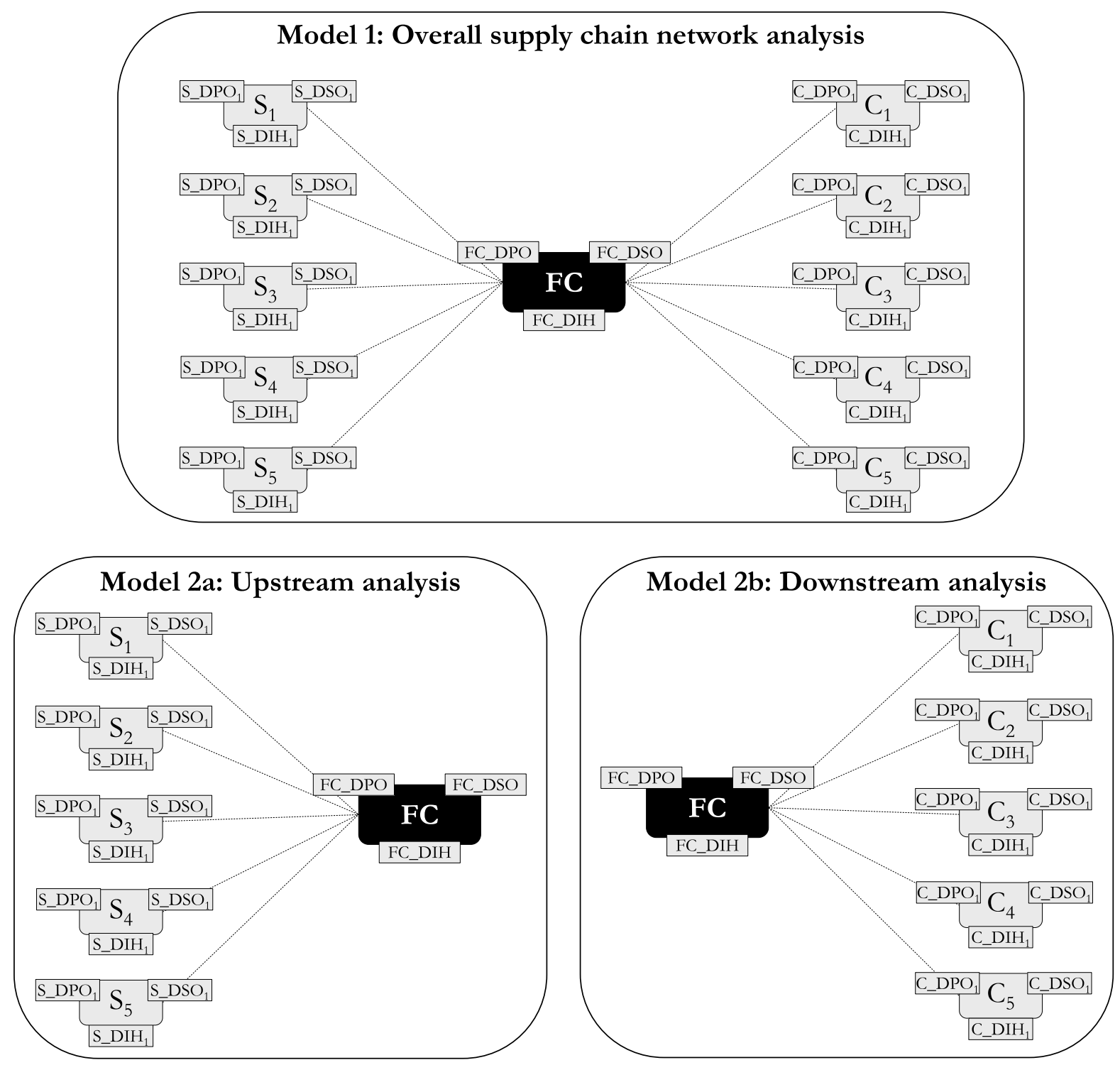

Fig. 6. Network perspectives of Models 1, 2a, and 2b.

sector (classification according to Bloomberg BICS). The same logic applies to Models 2a and 2b.

\subsection{Measures}

\subsubsection{Dependent variable}

We approximate corporate performance by the variable return on asset (ROA), because it is a widely used indicator for assessing the relationship between WCM and corporate performance (Jose et al., 1996; García-Teruel and Martínez-Solano, 2007; Sharma \& Kumar, 2011). More specifically, we compute ROA for the focal company (FC) according the following standard formula:

$F C \_R O A=\left(\frac{\text { NetIncome }}{\text { AverageTotalAssets }}\right)$

\subsubsection{Independent variables}

In the literature, ratios and cycle times are the two most common working capital measures. In this paper, we focus on the cash conversion cycle (CCC) and its components, not only because the CCC is a widely used measure of WCM in many other studies, such as García-
Teruel and Martínez-Solano (2007), Deloof (2003), and Richards and Laughlin (1980), but also because it is a typical measure for the capital management of an entire supply chain (Farris and Hutchison, 2002; Gelsomino et al., 2016).

The CCC () is calculated as the sum of DSO, DIH, and DPO (Richards and Laughlin, 1980) ${ }^{5}$

$$
\begin{gathered}
F C_{-} C C C_{i}=\left(\frac{\text { Accounts Re ceivables }}{\text { Sales }} \times 365\right)+\left(\frac{\text { Inventory }}{\text { Sales }} \times 365\right) \\
-\left(\frac{\text { AccountsPayable }}{\text { Sales }} \times 365\right)
\end{gathered}
$$

We do not decompose the CCC of the focal company into its three parts (DSO, DIH and DPO) as their individual effect on corporate performance has been widely studied from a single-company perspective (Deloof, 2003; Gill et al., 2010). However, we divide the CCC of a focal company's affiliated supply chain partners. There are two reasons for this. First, the relative importance of a supply chain partner's CCC

\footnotetext{
${ }^{5}$ Because we have an international sample of suppliers, customers, and focal firms, which do not necessarily all calculate their income statement after the cost-of-sales method (some use the full-cost method), the inventory and payables turns are based on a company's sales.
} 
Table 1

Properties and sample structures of the supply chain networks.

\begin{tabular}{llll}
\hline & Model1 & Model2a & Model2b \\
\hline Customers & 871 & 1043 & 899 \\
Suppliers & 973 & 1745 & 1457 \\
Focal companies & 293 & 549 & 447 \\
Total companies & 2137 & 3337 & 2803 \\
Networks & 290 & 320 & 287 \\
Focal companies & 290 & 320 & 287 \\
Customers & 864 & 950 & 848 \\
Suppliers & 964 & 1098 & 1001 \\
Total companies & 2118 & 2368 & 2136 \\
Networks with five customers & 99 & 109 & 97 \\
Networks with five suppliers & 128 & 154 & 138 \\
Complete networks & 71 & 80 & 74 \\
Manufacturing & $54 \%$ & $52 \%$ & $52 \%$ \\
Telecommunication & $30 \%$ & $32 \%$ & $31 \%$ \\
Consumer staples & $16 \%$ & $16 \%$ & $17 \%$ \\
Cost covered by suppliers & $10.91 \%$ & $10.32 \%$ & $10.76 \%$ \\
Revenue covered by customers & $12.71 \%$ & $12.84 \%$ & $12.43 \%$ \\
\hline
\end{tabular}

Notes: The first dividing line indicates values before and after listwise deletion; costs covered by suppliers represent the average COGS covered by the top suppliers in a supply chain network; revenue covered by customers represents the average revenue covered by the top customers in a supply chain network.

component is likely to decrease the less it is cross-linked with a focal company's working capital. For example, while an extension of payment terms by a customer (longer customer DPO) has a direct impact on a focal company's working capital (longer focal company DSO), it arguably also has a strong impact on a focal company's performance (FC_ROA). On the other hand, if a customer is changing its payment terms with downstream customers, the observable effect on a focal company's performance is arguably much smaller. Thus, the decomposition of the CCC of customers and suppliers allows us to analyze the varying WCM spillover intensities across single CCC components. Fig. 7 depicts this idea.

3.4.2.1. Upstream-related WCM variables. Supplier DSO () is measured as the weighted average DSO of the top suppliers of a focal firm, where the weights represent the percentage of costs (measured in COGS) that get incurred by a focal company for the respective supplier:

$S \_D S O=\frac{\sum_{i=1}^{n} \% \operatorname{Cost}_{S i} \times D S O_{S i}}{\sum_{i=1}^{n} \% \operatorname{Cost}_{S i}}$

Supplier DIH () is measured as the weighted average DIH of the top suppliers of a focal firm, where the weights represent the percentage of costs that get incurred by a focal company for the respective supplier:
$S \_D I H=\frac{\sum_{i=1}^{n} \% \operatorname{Cost}_{S i} \times D I H_{S i}}{\sum_{i=1}^{n} \% \operatorname{Cost}_{S i}}$

Supplier DPO () is measured as the weighted average DPO of the top suppliers of a focal firm, where the weights represent the percentage of costs that get incurred by a focal company for the respective supplier:

$S \_D P O=\frac{\sum_{i=1}^{n} \% \operatorname{Cost}_{S i} \times D P O_{S i}}{\sum_{i=1}^{n} \% \operatorname{Cos}_{S i}}$

3.4.2.2. Downstream-related WCM variables. The three downstreamrelated WCM variables, customer DSO (), customer DIH (), and customer DPO (), are calculated analogously to the upstream-related WCM variables of suppliers. Note, however, that the variables are weighted with the percentage of revenue that a focal company gets from the respective customer.

\subsubsection{Proxy variables}

Supply chain orientation (FC_SCO) of a focal company is measured as the five-year growth rate of a network's CCC:

$F C \_S C O=\frac{N E T \_C C C_{i}^{T 5}-N E T \_C C C_{i}^{T 1}}{N E T \_C C C_{i}^{T 1}}$

whereas T5 corresponds to year 2016 and T1 corresponds to year 2012. The network CCC () is calculated as the sum of the weighted average CCCs of the top suppliers, the weighted average CCCs of the top customers, and the (unweighted) CCC of the respective focal company. The weights of the suppliers are given by the percentage of costs that get incurred at the focal company, and the weights of the customers are given by the percentage of revenue that the focal company gets from the respective customer:

$$
\begin{gathered}
\text { NET_CCC }=\frac{\sum_{i=1}^{n} \% \operatorname{Cost}_{S i} \times C C_{C C} i}{\sum_{i=1}^{n} \% \text { Cost }_{S i}}+C C C_{F C i} \\
+\frac{\sum_{i=1}^{n} \% \text { Revenue }_{C i} \times C C C_{C i}}{\sum_{i=1}^{n} \% \text { Revenue } C i}
\end{gathered}
$$

It should be noted that this proxy measure for supply chain orientation provides a way to understand noncollaborative working capital improvements of a focal company as a zero-sum game. Systematic extensions (shortenings) of payment terms toward suppliers (customers) simply transfer working capital and financing costs to other stages in the supply chain (Hofmann and Kotzab, 2010). Fig. 8 depicts this idea. A win-win situation exists only when the CCC decreases simultaneously for all involved partners across the entire supply chain network. On this basis, the underlying assumption of this proxy variable is that if the CCC of the entire network has decreased during the five

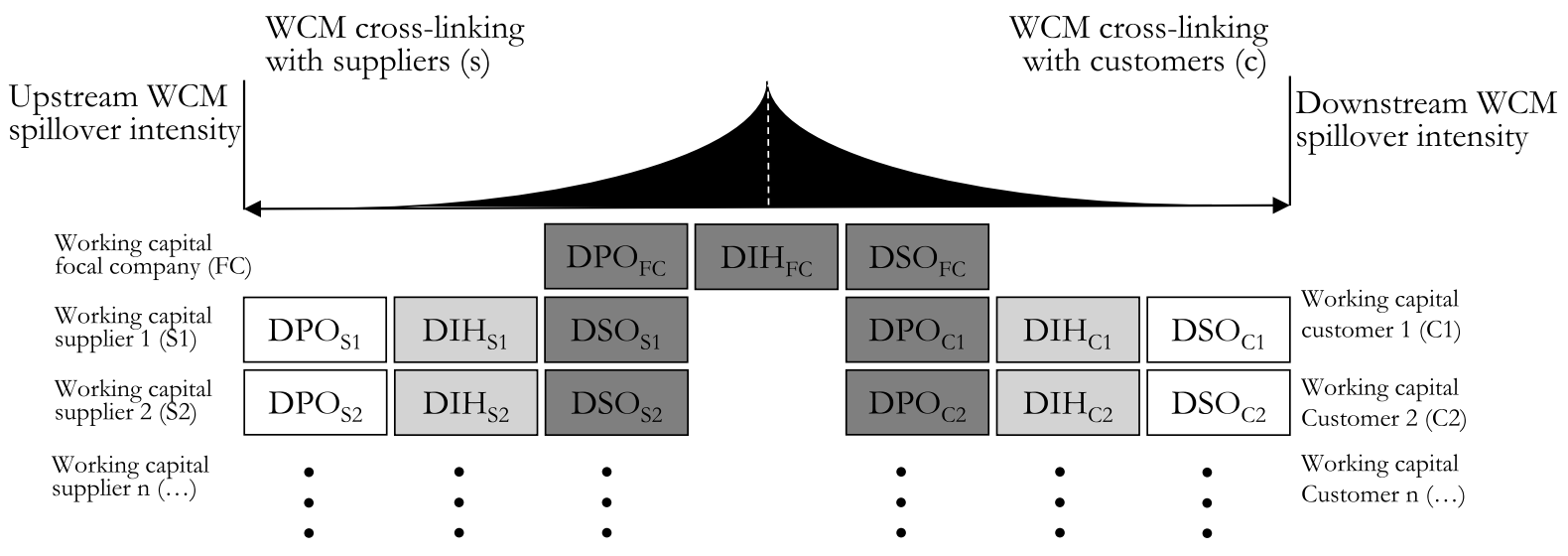

Fig. 7. Degree of WCM cross-linking and WCM spillover intensity within a focal company's supply chain network. 


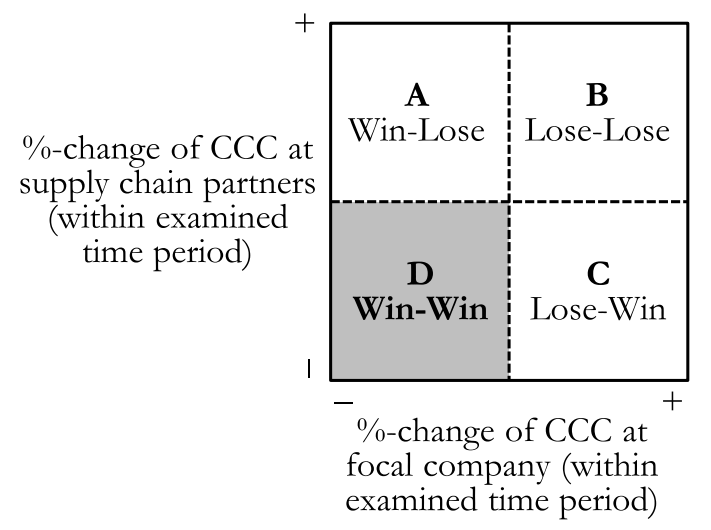

Fig. 8. Underlying assumption of the variable supply chain orientation.

year time period (2012-2016), a focal company has optimized its working capital collaboratively with its supply chain partners and has not simply shifted the working capital burden to the latter. For instance, implementing an innovative SCF solution, such as reverse factoring, allows a focal company to extend its DPO without lengthening its supplier DSO (Templar et al., 2016).

The degree of balance of the network in which a focal company operates (NET_BAL) is measured as the logarithmic sum of squared deviations from the (weighted) average CCCs in a network. The calculation of this variable is based on the following three-step procedure. First, we calculated the weighted average CCCs of a focal company's top suppliers and customers, respectively:

$S \_C C C=\frac{\sum_{i=1}^{n} \% \operatorname{Cost}_{S i} \times C C C_{S i}}{\sum_{i=1}^{n} \% \operatorname{Cost}_{S i}}$

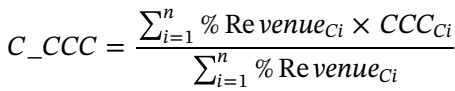

Second, we calculated the (weighted) average CCC of the entire supply chain network:

$\overline{N E T \_C C C}=\frac{1}{3}\left\{S_{-} C C C_{i}+C C C_{F C i}+C_{-} C C C_{i}\right\}$

Third, we computed the logarithmic sum of squared deviations (NET_BAL) from the weighted average CCCs in the network:

$$
\begin{gathered}
N E T \_B A L=\ln \left\{\left(\overline{N E T \_C C C_{i}}-S_{-} C C C_{i}\right)^{2}\right. \\
+\left(\overline{N E T \_C C C_{i}}-F C \_C C C_{i}\right)^{2} \\
\left.+\left(\overline{N E T \_C C C_{i}}-C_{-} C C C_{i}\right)^{2}\right\}
\end{gathered}
$$

Following the approach of Moyen (2004) and Baños-Caballero et al. (2014), we regard focal companies with a degree of balance above (below) the sample median as operating in a balanced (unbalanced) working capital supply chain network. Beyond that, we test for the absolute amount of working capital within a network with the variable NET_NWC, because it is arguably most advantageous to aim for balance across the supply chain on a low working capital level. Fig. 9 illustrates this concept with four different scenarios; scenario D is - from the perspective of capital tie-up - the preferred variant. We approximate NET_NWC as the weighted average level of net working capital within a network, relying on the standard definition of inventories plus accounts receivable less accounts payable (Afrifa, 2016).

Following Fazzari et al. (1988), we use dividend payments as a proxy variable to determine a firm's relative degree of financial constraints. However, contrary to Baños-Caballero et al. (2014), who split the data into zero- and positive-dividend groups, we use the centering method to create our proxy variables. There are two reasons for this. On one hand, it allowed us to examine the moderating relationship between the CCC and financial constraints more comprehensively, because the creation of dummy interactions is generally associated with a greater loss of information than is the creation of continuous interactions. On the other hand, by centering our variables, we were able to reduce the problem of multicollinearity in the product terms of the CCC and dividends (Howell, 2013). To center our variables , , , and , we created deviation scores by subtracting each variable's mean from the single-firm observation. Thereafter, we formed product terms with the respective centered variables. The variable "S_LFR" is calculated as the weighted average amount of dividend payments across the top 5 suppliers, where the weights represent the percentage of costs (measured in COGS) that get incurred by a focal company for the respective supplier. It is assumed that supply chain partners with limited financial resources tend to pay less dividend payments on average in order to keep costly external financing requirements on a low level. The final proxy variables included with respect to the upstream supply chain partners (suppliers) read as follows:

\subsubsection{Supplier proxies for financial constraints}

$$
\begin{aligned}
S \_L F R= & S \_L F R_{i}-S \_L F R_{i}^{\text {mean }} \\
S \_L F R \times & F C \_C C C=\left(S \_C C C_{i}-S \_C C C_{i}^{\text {mean }}\right) \\
& \times\left(S \_L F R_{i}-S \_L F R_{i}^{\text {mean }}\right) \\
S \_L F R \times & F C \_C C C \_S Q=\left(S \_C C C \_S Q_{i}-S \_C C C \_S Q_{i}^{\text {mean }}\right) \\
& \times\left(S \_L F R_{i}-S \_L F R_{i}^{\text {mean }}\right)
\end{aligned}
$$

The inclusion of these three variables allowed us to model the relationship between working capital and firm profitability and to test whether it changes as a function of a supplier's relative degree of financial constraints. We analogously calculated the proxy variables for the downstream supply chain partners (customers).

\subsubsection{Control variables}

We include additional variables in our models to control for other potential influences on corporate performance. Following previous studies (Deloof, 2003; Lazaridis and Tryfonidis, 2006), we include financial leverage (FC_LEV), which is measured as the ratio of total debt to total assets, as a control variable:

$F C \_L E V=\frac{\text { TotalDebt } \times 100}{\text { TotalAssets }}$

We control for company size, because it is known to affect a company's financial performance Baños-Caballero et al. (2014); Patatoukas (2012). We approximate company size (FC_SIZE) as the natural logarithm of sales:

FC_SIZE $=\ln$ Sales

Finally, we include a dummy variable for the consumer staples sector (CSS) and the telecommunication sector (TCS) in order to control for industry-specific effects.

\subsubsection{Models}

Using the variables explained above, we estimate three different models. Model 1 examines the functional form of working capital assets and corporate performance on the overall supply chain network level. We omit the constant and error terms, including subscripts for better readability, and define the model as follows:

$$
\begin{gathered}
F C \_R O A=\hat{\beta}_{1} F C \_L E V+\hat{\beta}_{2} F C \_S I Z E+\hat{\beta}_{3} F C \_C C C+\hat{\beta}_{4} F C \_C C C \_S Q \\
+\hat{\beta}_{5} S \_D S O+\hat{\beta}_{6} S \_D I H+\hat{\beta}_{7} S \_D P O \\
+\hat{\beta}_{8} F C \_S C O+\hat{\beta}_{9} N E T \_B A L \\
+\hat{\beta}_{11} C \_D S O+\hat{\beta}_{12} C \_D I H+\hat{\beta}_{13} C \_D P O \\
+\hat{\beta}_{13} T C S+\hat{\beta}_{14} C S S
\end{gathered}
$$




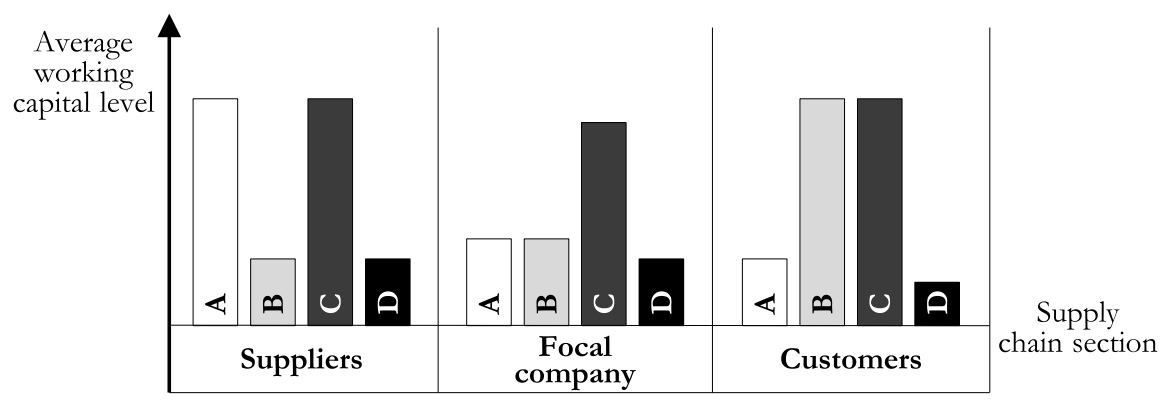

Scenario $\mathbf{A}=$ Unbalanced supply chain network towards suppliers

Scenario $\mathbf{B}=$ Unbalanced supply chain network towards customers

Scenario $\mathbf{C}=$ Balanced supply chain network on high working capital level

Scenario $\mathbf{D}=$ Balanced supply chain network on low working capital level

Fig. 9. Scenarios of balanced and unbalanced working capital levels within supply chain networks.

Model $2 a$ tests whether a focal company's profit-maximizing level of working capital changes when its upstream partners (suppliers) have limited financial resources:

$$
\begin{gathered}
F C \_R O A=\hat{\beta}_{1} F C \_L E V+\hat{\beta}_{2} F C \_S I Z E+\hat{\beta}_{3} F C \_C C C+\hat{\beta}_{4} F C \_C C C \_S Q \\
+\hat{\beta}_{5} S \_D S O+\hat{\beta}_{6} C \_D P O+\hat{\beta}_{7} N E T \_B A L+\hat{\beta}_{8} N E T \_N W C \\
+\hat{\beta}_{9} S \_L F R+\hat{\beta}_{10} S \_L F R \times F C \_C C C+\hat{\beta}_{11} S \_L F R \times F C \_C C C \_S Q
\end{gathered}
$$

Analogously, Model $2 b$ tests whether a focal company's profit-maximizing level of working capital changes when its downstream partners (customers) have limited financial resources:

$$
\begin{gathered}
F C \_R O A=\hat{\beta}_{1} F C \_L E V+\hat{\beta}_{2} F C \_S I Z E+\hat{\beta}_{3} F C \_C C C+\hat{\beta}_{4} F C \_C C C \_S Q \\
+\hat{\beta}_{5} S \_D S O+\hat{\beta}_{6} C \_D P O+\hat{\beta}_{7} N E T \_B A L+\hat{\beta}_{8} N E T \_N W C \\
+\hat{\beta}_{9} C \_L F R+\hat{\beta}_{10} C \_L F R \times F C \_C C C+\hat{\beta}_{11} C \_L F R \times F C \_C C C \_S Q
\end{gathered}
$$

The three perspectives of the models are illustrated in Fig. 6. Table 2 provides a summary of variable definitions.

\section{Explorative findings}

\subsection{Descriptives and correlation analysis}

The descriptive statistics of the variables used in Models 1, 2a, and
$2 \mathrm{~b}$ are summarized in Table 3 . The mean return on asset (FC_ROA) lies between 4.07 and 4.46 percent, and the mean leverage (FC_LEV) lies between 23.28 and 25.00. The mean focal company size (FC_SIZE) lies between 10.37 and 10.66. The mean cash conversion cycle (FC_CCC) in Model 1 is around 72 days, and in Model $2 \mathrm{a}$ and $2 \mathrm{~b}$, it is around 53 days, corresponding to the values found in similar studies (Lyngstadaas and Berg, 2016). Supplier DSO (S_DSO) is quite similar across the models, ranging from 60.82 to 63.56 . Equivalently, the mean value of customer DPO (C_DPO), with a range of $41.38-44.00$, is quite homogenous over the three samples. In Model 1 , the average DIH by the suppliers (S_DIH) is 48.57, which is higher than the average DIH by the customers (C_DIH) 43.53. The average DPO of the suppliers (S_DPO) is 40.11 , and the average DSO of the customers (C_DSO) is 62.16 .

Table 4 contains the correlation matrix for the variables included in Model 1. The results indicate a positive relationship between FC_CCC and FC_ROA and a negative relationship between the squared CCC FC_CCC_SQ and FC_ROA. The correlation between C_DPO and FC_ROA is negative at the 1-percent level of significance. Similarly, the correlation between S_DSO and FC_ROA is negative at the 5-percent level of significance. In addition, there is a negative relationship at the 1-percent level between NET_BAL and FC_ROA. The correlation between FC_LEV and FC_ROA is negative and significant at the 1-percent level, similar to the results obtained by Baños-Caballero et al. (2014). The

\begin{tabular}{|c|c|c|}
\hline Acronym & Variable & Description \\
\hline FC_ROA & Focal company's return on asset & Measures how efficiently the focal company uses its assets to generate earnings \\
\hline FC_LEV & Focal company's leverage ratio & Defines a focal company's total amount of debt relative to assets \\
\hline FC_SIZE & Focal company size & Defines a focal company's total of operating revenues less adjustments to gross sales \\
\hline FC_CCC & Focal company's cash conversion cycle & Length of time it takes a focal company to convert resource inputs into cash flows \\
\hline FC_CCC_SQ & Focal company cash conversion cycle squared & Defines the squared term of a focal company's cash conversion cycle \\
\hline NET_CCC & Network cash conversion cycle & Defines the weighted average CCC of the supply chain network in which a focal company operates \\
\hline FC_SCO & Supply chain orientation of a focal company & $\begin{array}{l}\text { Proxy variable for supply chain orientation, defined as the five-year growth rate of a focal company's } \\
\text { network CCC }\end{array}$ \\
\hline NET_BAL & Degree of network balance & Measures how evenly distributed working capital is within a focal company's supply chain network \\
\hline NET_NWC & Network net working capital & Approximates the total amount of working capital within a supply chain network \\
\hline S_DSO ${ }^{\mathrm{a}}$ & Supplier days sales outstanding & Weighted average number of days that the top-five suppliers of a focal company take to collect revenue \\
\hline S_DIH ${ }^{\mathrm{a}}$ & Supplier days inventory held & $\begin{array}{l}\text { Weighted average number of days that the top-five customers of a focal company take to sell } \\
\text { inventories }\end{array}$ \\
\hline $\mathrm{S}_{-} \mathrm{DPO}^{\mathrm{a}}$ & Supplier days payable outstanding & Weighted average number of days that the top-five suppliers of a focal company take to pay invoices \\
\hline$S_{-} L_{F R}{ }^{\mathrm{a}}$ & Supplier limited financial resources & Centered interaction variables for identifying financially constrained suppliers \\
\hline \multicolumn{3}{|c|}{$\begin{array}{l}\text { S LFR_FC CCC } \\
\text { S LFR_FC CCC SQ }\end{array}$} \\
\hline \multicolumn{3}{|r|}{$\mathrm{C} \mathrm{C}$} \\
\hline CSS & Telecommunication and Consumer staples & Define two industry dummy variables (the reference category is manufacturing) \\
\hline
\end{tabular}
Pearson correlation coefficient analysis of Models $2 \mathrm{a}$ and $2 \mathrm{~b}$ yields similar results and is summarized in Tables A.6 and A.7 in the appendix.

Notes: This table provides Pearson correlation coefficients for the

Table 2

Summary of variable definitions.

\footnotetext{
${ }^{a}$ Analogously, this also applies to the downstream-related customer WCM variables C DSO, C DIH, C DPO, C LFR, C LFR_FC CCC and C LFR_FC CCC SQ.
} 
Table 3

Descpritive statistics.

\begin{tabular}{|c|c|c|c|c|c|c|}
\hline Variables Model 1 & $\mathrm{~N}$ & Mean & Std. Dev. & Perc. 25 & Perc. 50 & Perc. 75 \\
\hline FC_ROA & 293 & 4.17 & 4.09 & 1.62 & 3.53 & 6.12 \\
\hline FC_LEV & 293 & 25.00 & 18.08 & 10.98 & 23.92 & 35.99 \\
\hline FC_SIZE & 293 & 10.39 & 2.71 & 8.46 & 10.01 & 12.18 \\
\hline FC_CCC & 293 & 71.95 & 64.09 & 29.35 & 70.16 & 102.63 \\
\hline FC_CCC_SQ & 293 & 9.07 & 14.74 & 0.86 & 4.92 & 10.66 \\
\hline S_DSO & 293 & 63.56 & 22.14 & 47.99 & 62.09 & 77.16 \\
\hline C_DPO & 290 & 41.38 & 19.18 & 29.13 & 39.46 & 50.44 \\
\hline FC_SCO & 293 & 0.06 & 0.24 & -0.07 & 0.02 & 0.17 \\
\hline S_DPO & 293 & 40.11 & 13.69 & 31.17 & 39.47 & 49.31 \\
\hline C_DSO & 293 & 62.16 & 32.52 & 39.37 & 57.50 & 81.18 \\
\hline C_DIH & 293 & 43.53 & 28.94 & 24.25 & 39.89 & 57.30 \\
\hline S_DIH & 293 & 48.57 & 26.05 & 29.49 & 44.47 & 64.31 \\
\hline Variables Model 2a & $\mathbf{N}$ & Mean & Std. Dev. & Perc. 25 & Perc. 50 & Perc. 75 \\
\hline FC_ROA & 549 & 4.07 & 4.44 & 1.48 & 3.39 & 6.15 \\
\hline FC_LEV & 549 & 24.68 & 18.01 & 10.20 & 23.31 & 35.99 \\
\hline FC_SIZE & 549 & 10.37 & 2.61 & 8.47 & 10.32 & 12.10 \\
\hline FC_CCC & 549 & 53.14 & 65.91 & 8.07 & 40.27 & 89.04 \\
\hline FC_CCC_SQ & 549 & 6.49 & 14.29 & 0.07 & 1.62 & 7.93 \\
\hline S_DSO & 549 & 60.82 & 23.07 & 44.04 & 59.67 & 73.38 \\
\hline C_DPO & 348 & 42.90 & 20.06 & 29.96 & 40.24 & 52.60 \\
\hline S_LFR & 399 & 0.00 & 2.78 & -1.61 & 0.04 & 1.64 \\
\hline S_LFR $\times$ FC_CCC & 397 & 1.97 & 160.41 & -45.71 & -0.72 & 69.57 \\
\hline S_LFR x FC_CCC_SQ & 399 & -3.44 & 46.41 & -6.84 & -0.32 & 7.61 \\
\hline Variables Model 2b & $\mathbf{N}$ & Mean & Std. Dev. & Perc. 25 & Perc. 50 & Perc. 75 \\
\hline FC_ROA & 447 & 4.46 & 4.33 & 1.92 & 3.74 & 6.55 \\
\hline FC_LEV & 447 & 23.28 & 16.95 & 9.99 & 22.33 & 33.32 \\
\hline FC_SIZE & 447 & 10.66 & 2.48 & 8.93 & 10.62 & 12.35 \\
\hline FC_CCC & 447 & 52.47 & 61.23 & 8.12 & 42.38 & 88.96 \\
\hline FC_CCC_SQ & 447 & 6.06 & 10.79 & 0.07 & 1.80 & 7.91 \\
\hline S_DSO & 447 & 61.33 & 22.91 & 44.75 & 59.82 & 73.57 \\
\hline C_DPO & 296 & 44.00 & 20.74 & 30.92 & 41.00 & 54.37 \\
\hline C_LFR & 447 & 0.10 & 2.95 & -1.74 & -0.03 & 1.79 \\
\hline C_LFR x FC_CCC & 447 & -2.38 & 176.86 & -46.70 & 6.97 & 72.24 \\
\hline C_LFR x FC_CCC_SQ & 447 & -1.51 & 28.55 & -6.98 & 0.82 & 9.18 \\
\hline
\end{tabular}

2118 companies across the 290 networks included in Model 1. *,*** and $* * *$ indicate significance at the $0.10,0.05$, and 0.01 level (two-tailed), respectively. FC_ROA is the earnings before interest, tax, and depreciation as a percentage of total assets; FC_LEV is the debt as a percentage of total assets; FC_SIZE is the natural logarithm of sales; FC_CCC is the cash conversion cycle; FC_CCC_SQ is the square of the cash conversion cycle; S_DSO is supplier days sales outstanding; C_DPO is customer days payable outstanding; NET_BAL is the degree of network; FC_SCO is the supply chain orientation; TCS is the consumer staples sector; CSS is the telecommunication sector; S_DPO is supplier days payable outstanding; C_DSO is customer days sales outstanding; C_DIH is customer days inventory held; S_DIH is supplier days inventory held.
Table 5

Coefficient output Models 1, 2a and 2b

\begin{tabular}{|c|c|c|c|}
\hline & Model 1 & Model 2a & Model 2b \\
\hline Variable & FC_ROA & FC_ROA & FC_ROA \\
\hline \multirow{2}{*}{ (Constant) } & $8.519^{* * *}$ & $5.66^{* * * *}$ & $9.424^{* * * *}$ \\
\hline & (1.701) & (1.429) & $(1.566)$ \\
\hline \multirow[t]{2}{*}{ FC_LEV } & $-0.039 * *$ & $-0.045^{* * *}$ & $-0.05^{* * *}$ \\
\hline & $(0.013)$ & $(0.013)$ & $(0.014)$ \\
\hline \multirow[t]{2}{*}{ FC_SIZE } & -0.123 & 0.062 & $-0.197^{*}$ \\
\hline & $(0.089)$ & (0.095) & (0.105) \\
\hline \multirow[t]{2}{*}{ FC_CCC } & $0.029^{* *}$ & $0.015^{*}$ & $0.025^{* *}$ \\
\hline & $(0.01)$ & $(0.008)$ & $(0.01)$ \\
\hline \multirow{2}{*}{ FC_CCC_SQ } & $-0.092^{*}$ & -0.057 & -0.081 \\
\hline & $(0.037)$ & $(0.042)$ & $(0.052)$ \\
\hline \multirow[t]{2}{*}{ S_DSO } & $-0.024 * *$ & -0.013 & $-0.019^{*}$ \\
\hline & $(0.012)$ & $(0.011)$ & (0.011) \\
\hline \multirow[t]{2}{*}{ C_DPO } & $-0.031 * *$ & $-0.022^{*}$ & $-0.029^{* *}$ \\
\hline & $(0.013)$ & $(0.012)$ & $(0.012)$ \\
\hline \multirow[t]{2}{*}{ NET_BAL } & $1.515^{* * *}$ & $0.669^{*}$ & $0.922^{*}$ \\
\hline & $(0.586)$ & $(0.525)$ & $(0.56)$ \\
\hline \multirow[t]{2}{*}{ NET_NWC } & & -1.015 & -0.892 \\
\hline & & $(0.509)$ & $(0.561)$ \\
\hline \multirow[t]{2}{*}{ C_LFR/S_LFR } & & -0.009 & $0.29 * *$ \\
\hline & & $(0.096)$ & (0.134) \\
\hline \multirow[t]{2}{*}{ C_LFR x FC_CCC/S_LFR x FC_CCC } & & $-0.007^{* *}$ & $-0.007^{* * *}$ \\
\hline & & $(0.003)$ & $(0.003)$ \\
\hline \multirow[t]{2}{*}{ C_LFR x FC_CCC_SQ/S_LFR x FC_CCC_SQ } & & $0.032^{*}$ & 0.033 \\
\hline & & $(0.017)$ & (0.019) \\
\hline \multirow[t]{2}{*}{ S_DPO } & -0.019 & & \\
\hline & $(0.018)$ & & \\
\hline \multirow[t]{2}{*}{ C_DSO } & 0.003 & & \\
\hline & $(0.008)$ & & \\
\hline \multirow[t]{2}{*}{ C_DIH } & -0.008 & & \\
\hline & $(0.01)$ & & \\
\hline \multirow[t]{2}{*}{ S_DIH } & -0.008 & & \\
\hline & $(0.011)$ & & \\
\hline \multirow[t]{2}{*}{ FC_SCO } & $2.63^{* * *}$ & & \\
\hline & (0.989) & & \\
\hline \multirow[t]{2}{*}{ TCS } & 0.235 & & \\
\hline & $(0.758)$ & & \\
\hline \multirow[t]{2}{*}{ CSS } & -0.318 & & \\
\hline & $(0.772)$ & & \\
\hline
\end{tabular}

\subsection{Working capital, supply chain finance, and corporate performance}

Table 5 shows the estimation results of Models 1, 2a, and 2b. Our findings indicate a profit-maximizing level of working capital, because the coefficient of FC_CCC is positive (0.029) and the coefficient of FC_CCC_SQ is negative $(-0.092)$ at the 10- and 5-percent level of significance, respectively. These findings are consistent with the results of previous studies based on the progressive theory (Mun and Jang, 2015;

Table 4

Pearson correlation coefficients Model 1.

\begin{tabular}{|c|c|c|c|c|c|c|c|c|c|c|c|c|c|c|}
\hline Variable & 1 & 2 & 3 & 4 & 5 & 6 & 7 & 8 & 9 & 10 & 11 & 12 & 13 & 14 \\
\hline FC_ROA & - & & & & & & & & & & & & & \\
\hline FC_LEV & $-.179 * *$ & - & & & & & & & & & & & & \\
\hline FC_SIZE & -.032 & .023 & - & & & & & & & & & & & \\
\hline FC_CCC & .030 & $-.189^{* *}$ & $-.155^{* *}$ & - & & & & & & & & & & \\
\hline FC_CCC_SQ & -.031 & $-.120^{*}$ & $-.186^{* *}$ & $.892^{* *}$ & - & & & & & & & & & \\
\hline S_DSO & $-.149^{*}$ & -.074 & .019 & $.178^{* *}$ & .088 & - & & & & & & & & \\
\hline C_DPO & $-.178 * *$ & .007 & $.149^{*}$ & .103 & $.127^{*}$ & $-.136^{*}$ & - & & & & & & & \\
\hline NET_BAL & $.135^{*}$ & $.184^{* *}$ & $.163^{* * *}$ & $-.462^{* *}$ & $-.384 * *$ & $-.229 * *$ & -.061 & - & & & & & & \\
\hline FC_SCO & $-.164^{* *}$ & .081 & -.076 & .072 & .086 & -.001 & .017 & -.022 & - & & & & & \\
\hline TCS & -.008 & $.294 * *$ & -.041 & $-.463^{* *}$ & $-.316^{* *}$ & -.081 & -.029 & $.278^{* *}$ & -.022 & - & & & & \\
\hline CSS & -.073 & -.009 & $.254 * *$ & $-.222^{* *}$ & $-.154 * *$ & $-.160 * *$ & -.100 & -.022 & -.009 & $-.278 * *$ & - & & & \\
\hline S_DPO & -.076 & -.070 & .005 & .077 & .073 & $.222^{* *}$ & $.226^{* *}$ & .044 & $-.152^{* *}$ & -.084 & .000 & - & & \\
\hline C_DSO & -.090 & $-.128^{*}$ & -.063 & $.294 * *$ & $.240 * *$ & $.371^{* *}$ & $.335^{* *}$ & $-.295^{* *}$ & $.119^{*}$ & $-.195 * *$ & $-.151^{* *}$ & $.122^{*}$ & - & \\
\hline C_DIH & -.078 & $-.130^{*}$ & $-.119^{*}$ & $.364 * *$ & $.275^{* * *}$ & .005 & .074 & $-.392^{* *}$ & .098 & $-.473^{* *}$ & .032 & .006 & $.163^{* *}$ & - \\
\hline S_DIH & -.088 & $-.147^{*}$ & -.088 & $.402^{* *}$ & $.270^{* * *}$ & $.230 * *$ & .115 & $-.392^{* *}$ & .020 & $-.532^{* *}$ & -.023 & $.153^{* *}$ & $.206^{* *}$ & $.475^{* *}$ \\
\hline
\end{tabular}




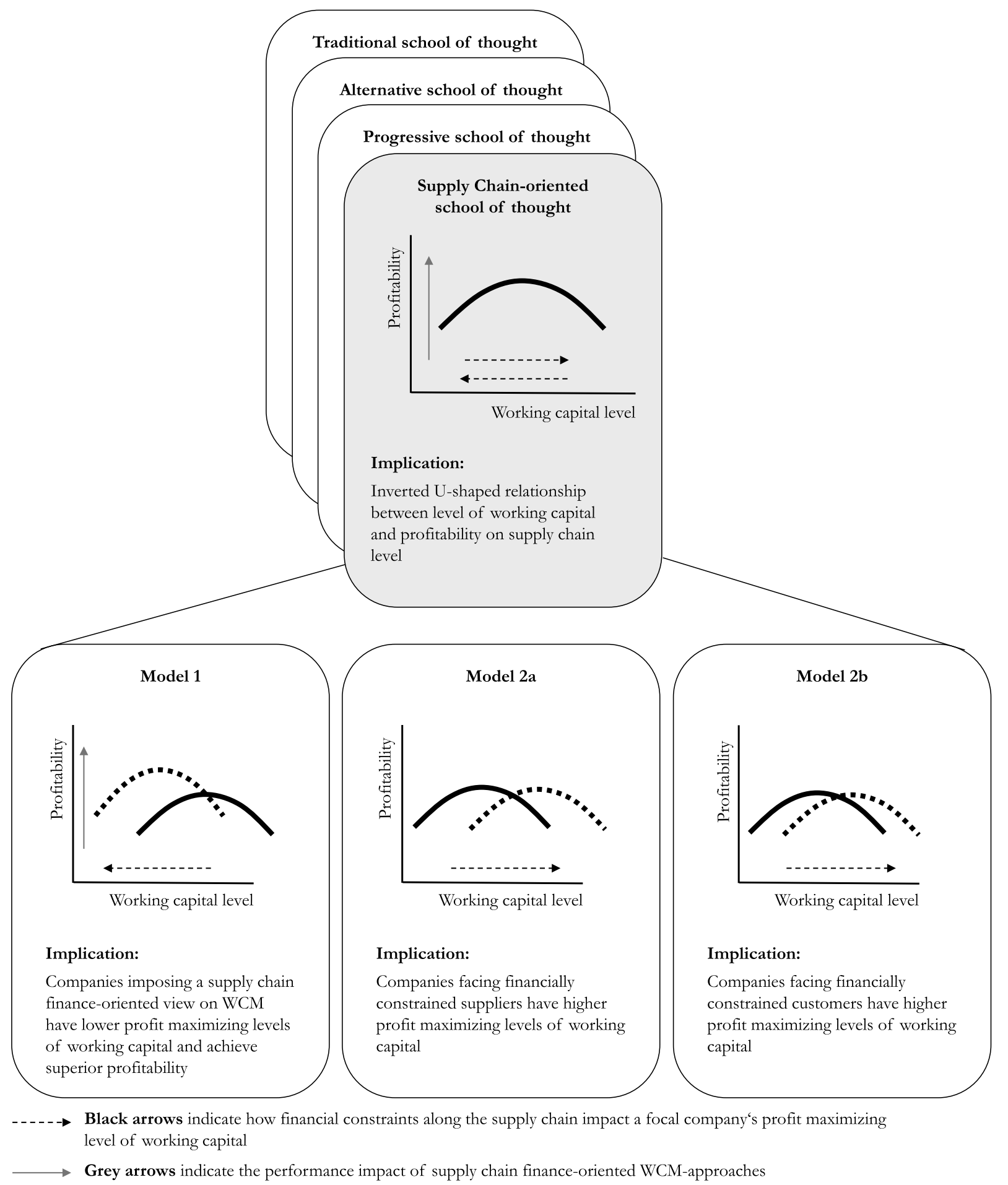

Fig. 10. Derived key propositions of Model 1, 2a and 2b.

Afrifa and Padachi, 2016; Altaf and Shah, 2017). The coefficient of the downstream-looking variable C_DPO $(-0.031)$ is negatively related to FC_ROA at the 5-percent level of significance. In contrast, the coefficient of the upstream-looking variable S_DSO $(-0.024)$, which reflects the counterpart of a focal company's DPO, is negatively related to FC_ROA at the 5-percent level, contradicting the results of Falope and Ajilore (2009). The variable S_DPO, which reflects the intertwining relationship between a focal company's tier-two and tier-one suppliers, is negative but insignificantly related to FC_ROA. Similarly, the variable C_DSO, which reflects the relationship between a focal company's tiertwo and tier-one customers, is slightly positive but insignificantly related to FC_ROA.

The two coefficients related to the inventories held at the suppliers (S_DIH) and customers (C_DIH) are both negative $(-0.008)$ but not statistically significant. Interestingly, the proxy variable NET_BAL is positively (1.515) related to FC_ROA and significant at the 5-percent 
level. Likewise, we find a significant positive relationship (2.63) at the 5-percent level between our proxy variable for SCF-oriented WCM approaches (FC_SCO) and FC_ROA. The industry control variables TCS and CSS are both insignificantly related to FC_ROA, which is in line with the findings of Hill et al. (2010) and Chiou et al. (2006). Finally, the control variables FC_SIZE and FC_LEV are both negatively related to FC_ROA, but only the latter is statistically significant at the 5-percent level.

\subsection{Impact of financially constrained supply chain partners}

Having tested the relationship between several working capital assets and corporate performance, we then explored whether this relationship is affected by the presence of financial constraints within a focal company's supply chain network. To account for this, we extended our baseline Model 1 by adding the interaction terms. Column 2 in Table 5 reports the results obtained from Model 2a, which we set up to examine whether a focal company's optimal level of working capital changes when its suppliers are financially constrained. Analogously, column 3 provides the estimation results of Model $2 \mathrm{~b}$, which we set up to examine whether a focal company's profit-maximizing working capital level is influenced by the presence of financially constrained customers.

The results confirm the existence of a concave relationship between working capital and corporate performance, because the variable FC_CCC is positively related and the variable FC_CCC_SQ negatively related with FC_ROA in all three models. These opposing effects, together with the interaction term variables, allowed us to quantify the degree to which the optimal CCC of a focal company changes when financial constraints are present (Baños-Caballero et al., 2014; Altaf and Shah, 2017). Interestingly, we found that a focal company's optimal CCC length increases by 29 days on average when its top customers are likely to be financially constraint. In addition, it turns out that this effect is even more pronounced with respect to the upstream supply chain partners. The optimal length of a focal companys CCC is on average 35 days longer when it faces suppliers that are likely to be financially constrained.

Regarding the variables S_DSO and C_DPO, which mirror the direct cross-organizational financing relationship of a focal company with its down- and upstream partners, we qualitatively found the same relationships as in Model 1 . Note that the coefficients of the variable C_DPO are significant in all three models. The variable NET_BAL is again positively related to $\mathrm{FC}_{-} \mathrm{ROA}$ in both models. Finally, we found a negative relationship between NET_NWC and FC_ROA. The R-squared values range from 0.107 to 0.165 , which is comparable to similar studies (Tauringana and Afrifa, 2013).

\section{Discussion: content-related implications and future research agenda}

We start this section with a content-related discussion of the explorative research results. We then derive a nonexhaustive list of methodological implications, pointing out how a new wave of largescale empirical SCF research can be triggered to address remaining shortcomings of our explorative network analysis.

\subsection{Implications of the explorative network analysis}

5.1.1. Implication 1: existence of a profit-maximizing level of working capital

As illustrated in Fig. 10, we find an inverted U-shaped relationship between the level of working capital and corporate performance in all three models, implying that companies indeed have to manage a tradeoff. This is especially true if one takes into account the working capital assets and financial wealth of the up- and downstream supply chain partners. Disinvestment in working capital can negatively impact a (focal) company's financial performance when the interorganizational costs and benefits are not adequately balanced. Our analysis therefore complements previous research on working capital valuation based on the progressive and SCF-oriented school of thought (Baños-Caballero et al., 2014; Altaf and Shah, 2017; Randall and Farris, 2009; Viskari and Kärri, 2012). It is also in line with previous work that has shown that shifting credit risk and capital costs toward suppliers can lead to negative distortions (Rafuse, 1996). It remains an open question which internal and external factors determine a (focal) company's performance-maximizing level of working capital. Our explorative network analysis, however, serves as a starting point and supports the idea that a comprehensive, SCF-oriented theory of WCM has to be developed by incorporating into the analysis those factors that lie beyond traditional company boundaries (Hofmann and Kotzab, 2010; Lee and Nam, 2016; Randall and Farris, 2009).

\subsubsection{Implication 2: superiority of SCF-oriented WCM approaches}

It seems to be beneficial for a company to operate in a "balanced" supply chain network, wherein all partners operate on the same (low) level of net working capital. Consistent with the conceptual work of Grosse-Ruyken et al. (2011), who argued that an adequate CCC for all players in the supply chain pays off, we identify a strong positive association between the balance of a supply chain network and a focal company's financial performance. Likewise, we find that focal companies imposing an SCF-oriented view on WCM achieve superior financial performance. Our empirical results are therefore consistent with previous conceptual studies claiming that collaborative WCM approaches lead to significant cost savings and improve performance on the chain level (Chandra \& Kumar, 2000; Hofmann and Kotzab, 2010; Protopappa-Sieke and Seifert, 2017). Accordingly, our results contribute to previous studies that have broadened the perspective on WCM and corporate performance on the supply chain network level (Caniato et al., 2016; Huff and Rogers, 2015; Carnovale et al., 2019). Our network analysis provides preliminary evidence of how SCF instruments such as reverse factoring, which allow a focal company to simultaneously reduce working capital together with its suppliers, can improve corporate performance (Wu et al., 2019). Importantly, it demonstrates that (focal) companies are well advised to refrain from systematically extending their payment terms to suppliers or from forcing their customers to pay earlier (Holter et al., 2010; Wuttke et al., 2016).

\subsubsection{Implication 3: relevance of financially constrained supply chain partners}

Our explorative results, summarized in Fig. 10, indicate that a focal company can improve its financial performance by extending its CCC in favor of its suppliers and customers when the latter have limited financial resources. These findings fundamentally contradict studies based on the traditional school of thought, which imply that companies should refrain from granting trade credit because it increases working capital, which is thought to have a negative impact on corporate performance (Deloof, 2003; Lazaridis and Tryfonidis, 2006). In contrast, we provide preliminary evidence that a single-company perspective is short-sighted (Randall and Farris, 2009; Walters, 2004). Our results are therefore in agreement with the redistribution view of trade credit provision (Meltzer, 1960; Petersen \& Rajan, 1997; Nilsen, 2002) and with the view that trade credit seems to be value enhancing, especially during tight economic times (Kahn et al., 2006; Ogden et al., 2005; Bititci et al., 2004). In this sense, our findings can also be linked back to Schwartz (1974), who pointed out decades ago that in maximizing their own profits, companies with a great deal of liquidity can offer their monetary resources to supply chain partners that have productive investment opportunities but are restricted in their ability to obtain 
capital. The relevance of our findings is particularly evident in today's business environment, where many cash-rich companies operate in lowinterest-rate environments. Rather than optimizing working capital in the sense of the traditional school of thought, leaving liquidity sitting in a low-interest bank account, they can draw on SCF solutions such as dynamic discounting, taking advantage of their excess cash. For instance, they can pay large invoices early to financially constrained suppliers, receiving additional purchasing discounts of several percent. This represents an obvious improvement on the bottom line for all involved supply chain partners.

\subsubsection{Implication 4: positive performance impact of collaborative inventory management}

Our results indicate that companies are likely to be affected by their affiliated supply chain partners' ability to efficiently manage inventories. This finding is consistent with previous conceptual studies claiming that companies, regardless of the position in the supply chain, should seek ways to collaboratively keep inventories on a low level (De Kok et al., 2005). It also accentuates the findings of earlier work on inventory management in supply chains in the WCM and SCF context (D'Avanzo et al., 2003; Hofmann, 2009; Greer and Theuri, 2012; Randall and Farris, 2009). Collaborative inventory management through decreased capital commitment costs, reduced frictions, and increased efficiency along the supply chain can be a critical contributor to a focal company's financial performance. This shows that SCF not only involves reverse factoring or dynamic discounting, but also represents a promising approach to exploiting untapped sources of enhanced financial performance by reducing tied-up capital in inventories within interorganizational settings.

\subsubsection{Implication 5: importance of differentiated payment terms strategy}

The supplier DSO (S_DSO) and customer DPO (C_DPO) variables, which reflect a focal company's financing relationships with its direct supply chain partners, are both significantly negatively related to a focal company's performance. Consequently, companies are well advised to implement a differentiated WCM strategy toward their up- and downstream supply chain partners. Previous studies have indicated that the further up the supply chain a company is, the more it should be prepared to bear the burden of higher working capital levels (Seifert, 2010; Lorentz et al., 2016). One explanation for this observation is that many firms follow a postponement business strategy in order to delay product investments until the last moment possible or that they follow a just-in-time production strategy in order to reduce own inventory levels (Anupindi and Jiang, 2008). These (pull) strategies related to the physical flows in the supply chain may help to reduce risks, inventory carrying costs, and flow times in a company. However, our results imply that it could be detrimental to apply the same strategy with respect to the financial flows in the supply chain. Referring payments to upstream suppliers as a means of increasing own liquidity seems to adversely effect a focal company's performance. Instead, companies should show interest in the tied-up working capital of their suppliers and aim to collaboratively reduce working capital with the help of innovative SCF instruments. Doing so could not only help to counterbalance the higher inventory burden of companies operating in the upstream supply chain, but also to ensure a balanced CCC along the supply chain, which seems to have a strong positive impact on corporate performance. In this sense, our paper builds on the approach of Cool and Henderson (1998), who contended that the power dynamics in upstream relationships differ from those in downstream supply chain relationships.

\subsection{Research agenda: methodological implications for future $S C F$ examinations}

In addition to the content-related implications, multiple methodological implications for future SCF research can be deduced from our analysis. The following nonexhaustive list is built around our limitations and makes no claim to completeness. Some of our modeling assumptions certainly open a door to debate; however, we think they present an enticing agenda for future SCF research. We restrict our discussion to questions that, from our point of view, require particular attention.

\section{- The appropriate perspective for WCM and SCF research}

Because accounts payable and accounts receivable mirror the crossorganizational financing relationship of a company with its supply chain partners, there is a need to analyze WCM and SCF in an interorganizational context. This imperative raises three important questions with regard to data collection: (i) which is the appropriate "level of analysis" (e.g., business unit vs. overall group)? (ii) which supply chain partners should be included? and (iii) where should the system boundary of the supply chain network be drawn?

We identified our supply chain networks by exploiting the SPLC data on Bloomberg. Consequently, all companies are stock listed, likely to be financially unconstrained, and relatively large with multiple business units. Hence, the generalizability of our results and implications is limited to large, financially unconstrained (focal) companies. Future research should analyze WCM on the interorganizational level for small and medium-sized companies, comparing the outcomes of these approaches.

Another potential threat to the reliability of our explorative analysis is its restriction to a focal company's top-five suppliers and customers. For instance, it could well be that a customer's average working capital is actually the result of another focal company's WCM strategy. In view of this limitation, we cannot exclude the possibility that our identified supply chain network partners are, for instance, simultaneously affected by their common business environments. Moreover, it may be the case that some networks overlap vertically or horizontally. Thus, future research must carefully specify and construct their system boundaries, preferably even more broadly than we did. For example, scholars could attempt to set the system boundary more widely in order to include the suppliers of the suppliers (subsuppliers) or the customers of the customers (end consumers). Our explorative research approach is sufficiently scalable to expand the supply chain perspective both horizontally (including more supply chain stages) and vertically (including more companies per supply chain stage). Therefore, future research can build on our analysis when integrating more supply chain partners and relaxing our underlying assumptions. In this context, it is also important to define and weigh which supply chain partners are considered in the analysis. For instance, we explicitly omitted relationships listed with selling, general, and administrative expenses (SG\&A) and capital expenditure (CapEx). Including those relationships would result in a broader and more varied network sample and potentially impact the underlying mechanism in the relationship between inter-organizational WCM and corporate performance.

\section{- Relevant theories for explaining interorganizational WCM and SCF phenomena}

Although the literature provides several definitions of SCF, academics agree that SCF represents a cross-disciplinary research field, encompassing the broadly defined finance, logistics, and SCM literature 
(Hofmann and Johnson, 2016). Previous empirical SCF research has reflected these intersections only partially. The research approach has been driven either by the finance perspective (Richards and Laughlin, 1980; Petersen \& Rajan, 1997; Deloof, 2003) or the logistiscs and SCM perspective (Wuttke et al., 2013a; Pfohl and Gomm, 2009). Jia et al. (2020) classify theories adopted by SCF papers into financial and organizational theories and state that most SCF papers reference back to the resource dependent and the agency theory. To ensure that all aspects are fully captured, future research should discuss major theories from different literature streams and determine how they can facilitate the explanation of interorganizational WCM and SCF phenomena. In addition to agency and transaction cost theory, approaches that address an (individual) company's optimal funding structure - such as the tradeoff theory - could serve as a promising starting point for adequately allocating working capital within supply chain networks (Dionne, 2011). However, future studies should also address mainstream theories in the logistics and SCM field in order to cover the interorganizational and relational aspects of SCF (Håkansson et al., 2010). They could do so, for instance, by integrating the contingency theory, which highlights the importance of achieving a fit between contextual supply chain network factors and response variables, or the resource dependency theory, which reveals how firms rely on other supply chain partners' (financial) resources (Ketchen and Hult, 2007; Sousa and Voss, 2008). Furthermore, multidisciplinary theories that have emerged from varied fields such as the network theory, employing a variety of different modeling techniques, have great potential for the analysis of financials in supply chain networks (Borgatti and Li, 2009; Galaskiewicz, 2011). Thus, future SCF research could make significant theoretical contributions by combining multiple and new theoretical lenses from a variety of disciplines.

\section{- Factors influencing a focal company's profit-maximizing level of working capital}

From both a theoretical and practical perspective, it is of central importance to understand which factors determine a (focal) company's financial performance-maximizing level of working capital and how working capital should be adequately allocated in a supply chain network (Protopappa-Sieke and Seifert, 2017). Coordination mechanisms of material flows across different functions and organizations is a major area of interest among researchers and practitioners. However, the study of financial (working capital) coordination and collaboration across different functions and organizations is still in its infancy and often excluded from researchers (Kaur et al., 2008; Marak and Pillai, 2019). In addition, papers analyzing the relationship between working capital and corporate performance have not considered internal and external factors to a sufficient extent. For instance, the work of BañosCaballero et al. (2014) and Altaf and Shah (2017) suggested that a company's optimal level of working capital is sensitive to its access to financial resources (an internal influencing factor). Our explorative study suggests that a (focal) company's profit-maximizing level of working capital is influenced by the presence of limited financial resources along the supply chain (an external influencing factor). Therefore, future SCF research needs to incorporate additional influencing factors and contingencies, in particular those that lie outside the traditional company boundaries. This includes industry-specific factors at the network level and the effect financial distress among supply chain partners that are connected to a focal company (Martin and Hofmann, 2019; Gibilaro and Mattarocci, 2019). Researchers who take on these challenges can provide valuable insights into the means of adequately allocating working capital in supply chain networks, maximizing the financial performance not only of a single company but of an entire supply chain network.

\section{- Identification and operationalization of SCF-oriented WCM ap- proaches}

SCF-oriented WCM approaches are not directly observable and are difficult to deduce from secondary data sources. Similarly, it is challenging to determine from publicly available data whether or not a company uses SCF solutions to manage its working capital collaboratively. Zhang et al. (2019) use the CCC as a proy for SCF solutions of a focal firm by providing liquidity to its up- and downstream supply chain partners. We operationalized the concept of supply chain orientation with the five-year growth rate of a network's CCC. Although we maintain that this is a reasonable proxy variable for this complex construct, it did not allow us to directly observe the true attitude of a focal company. Therefore, we can not conclusively state whether the decrease of a network's CCC is actually the result of a focal company's conscious decision to apply an SCF-oriented WCM approach or the result of other factors. Developing constructs for supply chain orientation via publicly available data is one possible avenue. However, the combination of statistics-based and survey-based measurement approaches could add greater validity to the inferences drawn (Engblom et al., 2012). Specifically, the body of WCM and SCF research may be advanced by using complementary secondary data sources, such as announcements in business publications, databases of newspapers, or newswires, to identify SCF companies. A good example is the study of Lam et al. (2019), who searched company websites, press realeases and news aggregators to identify SCF initiatives announced by Chines firms. The combination of a keyword search to identify SCF companies and classical financial secondary data sources could be a very powerful approach to analyzing the performance impact of SCF approaches in an interorganizational context. Thus far, the current literature has left this question largely unexplored.

\section{- Isolation of the performance impact of SCF-oriented WCM ap- proaches}

We tested our derived indications from previous literature with cross-sectional data, preventing us from drawing any dynamic inferences. In order to eliminate the unobservable heterogeneity, researchers generally estimate models using panel data methodology. The potential problems of endogeneity are alleviated by using the generalized method of moments (GMM) (Singhania and Mehta, 2017). However, due to the dynamic nature of supply chain networks, it is arguably misleading to use these standard econometric approaches to isolate the performance impact of SCF-oriented WCM approaches. A focal company's supplier and customer base may change over time, for example, due to new product developments, market changes, or company acquisitions. Thus, on the network level, it is challenging to control for all the factors that might covary with a focal company's corporate performance and to isolate the impact of collaborative SCF initiatives. Beyond that, we still know next to nothing about how the supply chain network structure impacts a focal company's performance-maximizing level of working capital. Future studies should apply more sophisticated modeling approaches and provide alternative research designs to analyze the various relationships between working capital, contextual network factors, and corporate performance. In addition, it is necessary for studies to take into account that supply chain networks are most likely not formed by an exogenous process, because actual firms probably do not "randomly" set up business relationships with other companies (Serpa and Krishnan, 2018). Against this background, it becomes evident that there are many unresolved fundamental methodological questions that need to be addressed by future SCF research. New methods, techniques, and models, while including an empirical perspective, have to be tested by drawing from various and extensive 
datasets.

\section{- Casual explanation of the performance impact of SCF-oriented WCM approaches}

Our findings suggest that operating in a "balanced" supply chain network and aiming for a collaborative WCM approach is beneficial for a focal company. In the current literature, only few indications can be found, providing (casual) reasoning behind this phenomena (GrosseRuyken et al., 2011; Monto, 2013). Future research should therefore aim to fill this gap, offering theoretical frameworks for identifying causal mechanisms behind the different performance impacts of SCForiented WCM approaches. This includes analyses that examine the financial performance effects on a focal company's affiliated supply chain partners. For instance, by means of event studies, it could be determined whether and how the introduction of a dynamic discounting or reverse factoring solution leads to a financial performance increase at suppliers, or whether the latter have benefited from other (nonfinancial) performance-enhancing effects. For this purpose, new indicators that go beyond financial indicators must be developed in order to investigate phenomena such as the strategic, risk, and operational impact of SCF initiatives. Thus, because SCF is an interorganizational phenomenon, future research should address questions about the causeand-effect relationships of SCF initiatives on the supply chain or network level.

\section{- Differences in the relational context between the up- and down- stream supply chain network}

Supply chain networks are complex with respect to their structure and relationships. Therefore it is important to consider differences in the relational context along a supply chain network. The assumption of most dyadic studies that the relational context in the upstream supply chain dyad (i.e., a supplier-focal firm dyad) mirrors that in a downstream supply chain dyad (i.e., a focal firm-customer dyad) is clearly too simplistic (Lanier et al., 2010; Chen et al., 2004; Cool and Henderson, 1998). Future SCF research should therefore energetically address these distinctions and investigate, for instance, how market power affects the trade credit granting behavior toward up- and downstream supply chain partners (Wilner, 2000; Kelly and Gosman, 2000). Another limitation of our study is that we focused on only one measure to identify financially constrained supply chain partners, although there is an extensive debate in the scientific community on how to best identify the latter (Fazzari and Petersen, 1993; Carpenter et al., 1994; Baños-Caballero et al., 2014). In order to classify and cluster companies correctly, we require a more precise understanding of how frictions in the supply of capital along the supply chain can lead to financial constraints. Therefore, future research should develop and investigate additional proxy variables such as cumulative cost of external financing or interest coverage within supply chain networks.

\section{Conclusion}

Whereas most previous empirical studies based on secondary financial data have applied a single-company perspective (e.g. Deloof, 2003; Baños-Caballero et al., 2014), we analyze the relationship between working capital assets and corporate performance in an interorganizational supply chain setting. In doing so, we follow previous conceptual research taking into account that a focal company's financing relationships are bound by the supply chain network in which they are embedded (Hofmann and Kotzab, 2010; Grosse-Ruyken et al., 2011). Based on our explorative examination, we provide preliminary empirical insights, suggesting that there is an inverted U-shaped relationship between working capital and corporate performance (RQ1). We show that this relationship is affected by the presence of financial constraints along the supply chain. Specifically, we report that the profit-maximizing level of working capital increases for focal companies when they face financially constrained supply chain partners (RQ2). This finding fundamentally contradicts the traditional WCM school of thought (Singh et al., 2017; Jose et al., 1996), which advises practitioners to reduce working capital at all cost. Moreover, our analysis suggests - following the indications of typical SCF studies such as Camerinelli (2009), Caniato et al. (2016), and Hofmann and Zumsteg (2015) - that focal companies that manage their working capital collaboratively achieve superior financial performance (RQ3). In particular, our findings suggest that companies should strive for a balanced CCC across the supply chain network and should consider the tied-up working capital at their supply chain partners when optimizing their own working capital. Most importantly, our results emphasize that companies can increase their financial performance by applying a collaborative SCF approach.

In this light, our paper makes several theoretical contributions to SCF-related literature. First, by analyzing the role of financially constrained supply chain partners, it contributes to the literature on working capital valuation (Deloof, 2003; Lazaridis and Tryfonidis, 2006; Baños-Caballero et al., 2014; Altaf and Shah, 2017). Second, it improves the theoretical understanding of how working capital should be adequately allocated in a supply chain network (Gupta and Dutta, 2011; Randall and Farris, 2009; Hofmann and Kotzab, 2010; Viskari and Kärri, 2012; Protopappa-Sieke and Seifert, 2017). Third, by shifting the modeling perspective to the supply chain network level, the paper accentuates earlier SCF research and improves the theoretical understanding of how a company's profit-maximizing level of working capital is determined by external factors, on one hand, and the affiliated supply chain partners, on the other. Fourth, we provide researchers who intend to contribute to this field with several methodological hints.

From a managerial point of view, our paper assists practitioners in developing an integrated SCF-oriented WCM approach. It not only guides them on how to strategically manage financially constraint partners, but also improves their understanding of how to adequately allocate working capital in a supply chain network. Moreover, it demonstrates that collaborative WCM and SCF offers an avenue for improving corporate financial performance. Most importantly, it highlights that from the interorganizational network perspective propagated by the SCF-oriented school of thought, the managerial implications derived from traditional WCM studies fall short.

To sum up, our explorative analysis is only a first step in analyzing working capital beyond the traditional single-company perspective and represents a starting point for several further studies. With the proposed research agenda, we hope to inspire future empirical network analyses that refine the many methodological issues that need to be solved and answer the many research questions that remain to be explored in developing an SCF-oriented WCM school of thought. 


\section{Appendix A}

Table A.6Pearson correlation coefficients Model 2a

\begin{tabular}{|c|c|c|c|c|c|c|c|c|c|c|c|}
\hline Variable & 1 & 2 & 3 & 4 & 5 & 6 & 7 & 8 & 9 & 10 & 11 \\
\hline FC_ROA & - & & & & & & & & & & \\
\hline FC_LEV & $-.232^{* *}$ & - & & & & & & & & & \\
\hline FC_SIZE & -.032 & .011 & - & & & & & & & & \\
\hline FC_CCC & .002 & $-.112^{* *}$ & $-.145^{* *}$ & - & & & & & & & \\
\hline FC_CCC_SQ & -.020 & -.079 & $-.137^{* *}$ & $.869^{* *}$ & - & & & & & & \\
\hline S_DSO & -.083 & -.045 & -.026 & $.246^{* *}$ & $.154 * *$ & - & & & & & \\
\hline C_DPO & $-.137^{*}$ & -.011 & $-.108^{*}$ & -.028 & .045 & .093 & - & & & & \\
\hline S_LFR & -.091 & .076 & $.421^{* *}$ & -.021 & -.092 & $.132^{* *}$ & -.095 & - & & & \\
\hline S_LFR x FC_CCC & -.054 & .021 & .056 & $-.186^{* *}$ & $-.205^{* *}$ & .005 & -.101 & $.144^{* *}$ & - & & \\
\hline S_LFR X FC_CCC_SQ & .016 & .034 & .040 & $-.316^{* *}$ & $-.506^{* *}$ & .035 & -.074 & $.112^{*}$ & $.904 * *$ & - & \\
\hline NET_BAL & .051 & $.188^{* * *}$ & $.141^{* *}$ & $-.450 * *$ & $-.387^{* *}$ & $-.250^{* *}$ & -.006 & $.148^{* *}$ & .087 & $.113^{*}$ & - \\
\hline NET_NWC & -.087 & $-.116^{*}$ & $.458^{* *}$ & -.005 & -.065 & $.131 *$ & .019 & $.499 * *$ & $.230 * *$ & $.138^{*}$ & -.010 \\
\hline
\end{tabular}

Notes: This table provides Pearson correlation coefficients for the 2368 companies across the 320 networks included in Model 2a. All variables are explained in detail in chapter three. $* * *$, and $* * *$ indicate that the correlation is significant at the $0.10,0.05$, and 0.01 level (two-tailed), respectively. FC_ROA is the earnings before interest, tax, and depreciation as a percentage of total assets; FC_LEV is the debt as a percentage of total assets; FC_SIZE is the natural logarithm of sales; FC_CCC is the cash conversion cycle; FC_CCC_SQ is the square of the cash conversion cycle; S_DSO is supplier days sales outstanding; C_DPO is customer days payable outstanding; S_LFR, S_LFR FC_CCC and S_LFR FC_CCC_SQ are the centered proxy variables for the relative degree of financial constraints of customers; NET_BAL is the degree of network balance; N_NWC is the network net working capital.

\section{Table A.7Pearson correlation coefficients Model 2b}

\begin{tabular}{|c|c|c|c|c|c|c|c|c|c|c|c|}
\hline Variable & 1 & 2 & 3 & 4 & 5 & 6 & 7 & 8 & 9 & 10 & 11 \\
\hline FC_ROA & - & & & & & & & & & & \\
\hline FC_LEV & $-.240 * *$ & - & & & & & & & & & \\
\hline FC_SIZE & $-.107^{*}$ & .038 & - & & & & & & & & \\
\hline FC_CCC & .017 & $-.108^{*}$ & $-.197^{* *}$ & - & & & & & & & \\
\hline FC_CCC_SQ & -.014 & -.093 & $-.198^{* *}$ & $.898 * *$ & - & & & & & & \\
\hline S_DSO & $-.096^{*}$ & -.048 & -.030 & $.266^{* *}$ & $.189^{* * *}$ & - & & & & & \\
\hline C_DPO & $-.169 * *$ & .003 & $-.137^{*}$ & -.046 & .037 & .109 & - & & & & \\
\hline C_LFR & -.057 & $.112^{*}$ & $.384 * *$ & -.013 & -.046 & .059 & -.049 & - & & & \\
\hline C_LFR x FC_CCC & .041 & -.016 & .055 & .003 & -.073 & -.046 & -.085 & $-.143^{* *}$ & - & & \\
\hline C_LFR x FC_CCC_SQ & .057 & -.005 & .013 & -.080 & $-.160^{* *}$ & -.065 & -.058 & $-.166^{* *}$ & $.905^{* *}$ & - & \\
\hline NET_BAL & .045 & $.228^{* *}$ & $.142^{*}$ & $-.417^{* *}$ & $-.393^{* *}$ & $-.277^{* *}$ & -.014 & $.123^{*}$ & .062 & .088 & - \\
\hline NET_NWC & $-.166^{* *}$ & -.080 & $.434 * *$ & .005 & -.044 & $.139^{*}$ & .002 & $.701^{* *}$ & .111 & .063 & -.031 \\
\hline
\end{tabular}

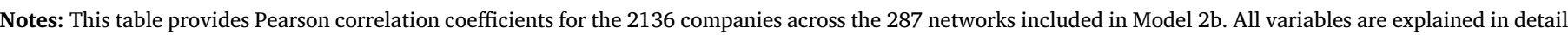

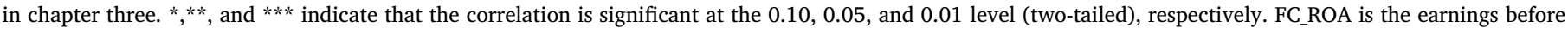

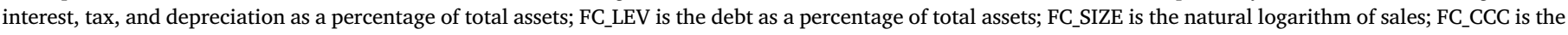

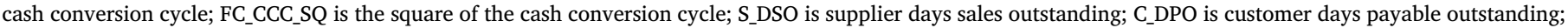

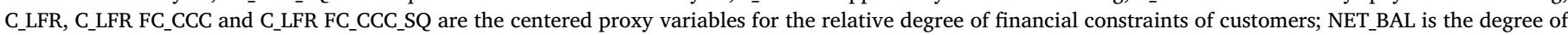
network balance; N_NWC is the network net working capital.

\section{References}

Afrifa, G.A., 2016. Net working capital, cash flow and performance of UK SMEs. Rev. Account. Finance 15 (1), 21-44.

Afrifa, G.A., Padachi, K., 2016. Working capital level influence on SME profitability. J. Small Bus. Enterp. Dev. 23 (1), 44-63.

Alarussi, A.S., Alhaderi, S.M., 2018. Factors affecting profitability in Malaysia. J. Econ. Stud. 45 (3), 442-458.

Altaf, N., Shah, F., 2017. Working capital management, firm performance and financial constraints. Asia-Pac. J. Business Admin. 9 (3), 206-219.

Anupindi, R., Jiang, L., 2008. Capacity investment under postponement strategies, market competition, and demand uncertainty. Manag. Sci. 54 (11), 1876-1890.

Autukaite, R., Molay, E., 2014. Cash holdings, working capital and firm value: evidence from France. Banker. Market. Invest. 132, 53-62.

Axsater, S., Rosling, K., 1993. Installation vs. echelon stock policies for multilevel inventory control. Manag. Sci. 39 (10), 1274-1280.

Baños-Caballero, S., García-Teruel, P.J., Martínez-Solano, P., 2014. Working capital management, corporate performance, and financial constraints. J. Bus. Res. 67 (3), 332-338.

Belt, B., Smith, K.V., 1991. Comparison of working capital management practices in Australia and the United States. Glob Financ. J. 2 (1), 27-54.

Bernabucci, R.J., 2008. Supply chain gains from integration. Financ. Exec. 24 (3), 46-48.

Bian, Y., Lemoine, D., Yeung, T.G., Bostel, N., Hovelaque, V., Viviani, J.-L., Gayraud, F., 2018. A dynamic lot-sizing-based profit maximization discounted cash flow model considering working capital requirement financing cost with infinite production capacity. Int. J. Prod. Econ. 196, 319-332.

Bititci, U.S., Martinez, V., Albores, P., Parung, J., 2004. Creating and managing value in collaborative networks. Int. J. Phys. Distrib. Logist. Manag. 34 (3), 251-268.

Blackman, I.D., Holland, C.P., Westcott, T., 2013. Motorola's global financial supply chain strategy. Supply Chain Manag.: Int. J. 18 (2), 132-147.

Blazenko, G.W., Vandezande, K., 2003. The product differentiation hypothesis for corporate trade credit. Manag. Decis. Econ. 24 (6-7), 457-469.

Blinder, A.S., Maccini, L.J., 1991. The resurgence of inventory research: what have we learned? J. Econ. Surv. 5 (4), 291-328.

Boissay, F., Gropp, R., 2007. Trade credit defaults and liquidity provision by firms, ECB working paper. 753.

Borgatti, S.P., Li, X., 2009. On social network analysis in a supply chain context. J. Supply Chain Manag. 45 (2), 5-22.

Brandenburg, M., 2016. Supply chain efficiency, value creation and the economic crisis an empirical assessment of the European automotive industry 2002-2010. Int. J. Prod. Econ. 171 (3), 321-335.

Busi, M., Bititci, U.S., 2006. Collaborative performance management: present gaps and future research. Int. J. Product. Perform. Manag. 55 (1), 7-25.

Camerinelli, E., 2009. Supply chain finance. J. Payments Strategy \& Syst. 3 (2), 114-128.

Caniato, F., Gelsomino, L.M., Perego, A., Ronchi, S., 2016. Does finance solve the supply chain financing problem? Supply Chain Manag.: Int. J. 21 (5), 534-549.

Carnovale, S., Rogers, D.S., Yeniyurt, S., 2019. Broadening the perspective of supply chain finance: the performance impacts of network power and cohesion. J. Purch. Supply Manag. 25 (2), 134-145. 
Carpenter, R.E., Fazzari, S.M., Petersen, B.C., 1994. Inventory investment, internal-finance fluctuations, and the business cycle. Brook. Pap. Econ. Act. (2), 75-122.

Carter, C.R., Rogers, D.S., Choi, T.Y., 2015. Toward the theory of the supply chain. J. Supply Chain Manag. 51 (2), 89-97.

Cavenaghi, E., 2013. Supply chain finance: the new frontier in the world of payment. J. Payments Strategy \& Syst. 7 (4), 290-293.

Chandra, C., Kumar, S., 2000. Supply chain management in theory and practice: a passing fad or a fundamental change? Ind. Manag. Data Syst. 100 (3), 100-114.

Chang, C.-C., 2018. Cash conversion cycle and corporate performance: global evidence. Int. Rev. Econ. Financ. 56, 568-581.

Chen, I.J., Paulraj, A., Lado, A.A., 2004. Strategic purchasing, supply management, and firm performance. J. Oper. Manag. 22 (5), 505-523.

Chiou, J.R., Cheng, L., Wu, W.D., 2006. The determinants of working capital management. J. Am. Acad. Business 10 (1), 149-155.

Cohen, L., Morrison, K., Manion, L., 2011. Research Methods in Education, seventh ed. Routledge, London.

Cool, K., Henderson, J., 1998. Power and firm profitability in supply chains: French manufacturing industry in 1993. Strat. Manag. J. 19 (10), 909-926.

Cooper, M.C., Lambert, D.M., Pagh, J.D., 1997. Supply chain management: more than a new name for logistics. Int. J. Logist. Manag. 8 (1), 1-14.

Cunat, V., 2007. Trade credit suppliers as debt collectors and insurance providers. Rev. Financ. Stud. 20 (2), 491-527.

D'Avanzo, R., von Lewinski, H., van Wassenhove, L.N., 2003. The link between supply chain and financial performance. Supply Chain Manag. Rev. 7 (6), 40-47.

De Kok, T., Janssen, F., Van Doremalen, J., Van Wachem, E., Clerkx, M., Peeters, W., 2005. Philips electronics synchronizes its supply chain to end the bullwhip effect. Interfaces 35 (1), 37.

Deloof, M., 2003. Does working capital management affect profitability of Belgian firms? J. Bus. Financ. Account. 30 (3-4), 573-588.

Deloof, M., Jegers, M., 1996. Trade credit, product quality, and intragroup trade: some European evidence. Financ. Manag. (3), 33-43.

Dionne, G., 2011. The theory of corporate finance, by jean tirole. J. Risk Insur. 78 (3), 791-793.

Drucker, P.F., 1962. The economy's dark continent. Fort. Magaz. Archive 65 (4), 103-270 (1930-2000).

Emery, G.W., 1984. A pure financial explanation for trade credit. J. Financ. Quant. Anal. 19 (3), 271-285.

Engblom, J., Solakivi, T., Töyli, J., Ojala, L., 2012. Multiple-method analysis of logistics costs. Int. J. Prod. Econ. 137 (1), 29-35.

Eroglu, C., Hofer, C., 2011. Lean, leaner, too lean? The inventory-performance link revisited. J. Oper. Manag. 29 (4), 356-369.

Falope, O.I., Ajilore, O.T., 2009. Working capital management and corporate profitability: evidence from panel data analysis of selected quoted companies in Nigeria. Res. J. Bus. Manag. 3 (3), 73-84.

Farris, M.T., Hutchison, P.D., 2002. Cash-to-cash: the new supply chain management metric. Int. J. Phys. Distrib. Logist. Manag. 32 (4), 288-298.

Fazzari, S.M., Hubbard, R.G., Petersen, B.C., 1988. Financing constraints and corporate investment. Brook. Pap. Econ. Act. 1, 141-206.

Fazzari, S.M., Petersen, B.C., 1993. Working capital and fixed investment: new evidence on financing constraints. Rand J. Econ. 24 (3), 328-342.

Galaskiewicz, J., 2011. Studying supply chains from a social network perspective. J. Supply Chain Manag. 47 (1), 4-8.

García-Teruel, P.J., Martínez-Solano, P., 2007. Effects of working capital management on SME profitability. Int. J. Manag. Financ. 3 (2), 164-177.

Gaski, J.F., Ray, N.M., 2004. Alienation in the distribution channel conceptualization, measurement, and initial theory testing. Int. J. Phys. Distrib. Logist. Manag. 34 (2), 158-200.

Gelsomino, L.M., Mangiaracina, R., Perego, A., Tumino, A., 2016. Supply chain finance: a literature review. Int. J. Phys. Distrib. Logist. Manag. 46 (4), 348-366.

Gentry, J.A., Vaidyanathan, R., Lee, H.W., 1990. A Weighted Cash Conversion Cycle. Financial Management. vol. 19. Wiley-Blackwell), pp. 90-99 1.

Gibilaro, L., Mattarocci, G., 2019. The impact of corporate distress along the supply chain: evidences from United States. Supply Chain Manag.: Int. J. 24 (4), 498-508.

Gill, A., Biger, N., Mathur, N., 2010. The relationship between working capital management and profitability: evidence from the United States. Bus. Econ. J. 10 (1), 1-9.

Greer, B.M., Theuri, P., 2012. Linking supply chain management superiority to multifaceted firm financial performance. J. Supply Chain Manag. 48 (3), 97-106.

Grosse-Ruyken, P.T., Wagner, S.M., Jonke, R., 2011. What is the right cash conversion cycle for your supply chain? Int. J. Serv. Oper. Manag. 10 (1), 13-29.

Gupta, S., Dutta, K., 2011. Modeling of financial supply chain. Eur. J. Oper. Res. 211 (1), $47-56$.

Håkansson, H., Lind, J., Kraus, K., 2010. Accounting in Networks, first ed. Routledge, New York, NY.

Håkansson, H., Persson, G., 2004. Supply chain management: the logic of supply chains and networks. Int. J. Logist. Manag. 15 (1), 11-26.

Hill, M.D., Kelly, G.W., Highfield, M.J., 2010. Net operating working capital behavior: a first look. Financ. Manag. 39 (2), 783-805.

Hofmann, E., 2009. Inventory financing in supply chains: a logistics service providerapproach. Int. J. Phys. Distrib. Logist. Manag. 39 (9), 716-740.

Hofmann, E., Johnson, M., 2016. Supply chain finance (SCF) - some conceptual thoughts reloaded. Int. J. Phys. Distrib. Logist. Manag. 46 (4), 342-347.

Hofmann, E., Kotzab, H., 2010. A supply chain-oriented approach of working capital management. J. Bus. Logist. 31 (2), 305-330.

Hofmann, E., Zumsteg, S., 2015. Win-win and no-win situations in supply chain finance: the case of accounts receivable programs. Supply Chain Forum Int. J. 16 (3), 30-50.

Holter, A.R., Grant, D.B., Ritchie, J.M., Shaw, W.N., Towers, N.S., 2010. Long-range transport: speeding up the cash-to-cash cycle. Int. J. Logist. Res. Appl. 13 (5), 339-347.

Howell, D.C., 2013. Statistical Methods for Psychology, eighth ed. Wadsworth Cengage Learning, Belmont, California.

Huff, J., Rogers, D.S., 2015. Funding the organization through supply chain finance: a longitudinal investigation. Supply Chain Forum Int. J. 16 (3), 4-17.

Hult, G.T.M., Ketchen, D.J., Griffith, D.A., Chabowski, B.R., Hamman, M.K., Dykes, B.J., Pollitte, W.A., Cavusgil, S.T., 2008. An assessment of the measurement of performance in international business research. J. Int. Bus. Stud. 39 (6), 1064-1080.

Jia, F., Blome, C., Sun, H., Yang, Y., Zhi, B., 2020. Towards an integrated conceptual framework of supply chain finance: an information processing perspective. Int. J. Prod. Econ. 219, 18-30.

Jose, M.L., Lancaster, C., Stevens, J.L., 1996. Corporate returns and cash conversion cycles. J. Econ. Financ. 20 (1), 33-46.

Kahn, K.B., Maltz, E.N., Mentzer, J.T., 2006. Demand collaboration: effects on knowledge creation, relationships, and supply chain performance. J. Bus. Logist. 27 (2), $191-221$.

Kaur, A., Kanda, A., Deshmukh, S.G., 2008. Supply chain coordination: perspectives, empirical studies and research directions. Int. J. Prod. Econ. 115 (2), 316-335.

Kelly, T., Gosman, M.L., 2000. Increased buyer concentration and its effects on profitability in the manufacturing sector. Rev. Ind. Organ. 17 (1), 41-59.

Ketchen, D.J., Hult, G.T.M., 2007. Bridging organization theory and supply chain management: the case of best value supply chains. J. Oper. Manag. 25 (2), 573-580.

Khoury, N.T., Smith, K.V., MacKay, P.I., 1999. Comparing working capital practices in Canada, the United States, and Australia: a note. Can. J. Admin. Sci. 16 (1), 53-57.

Kim, Y.H., Henderson, D., 2015. Financial benefits and risks of dependency in triadic supply chain relationships. J. Oper. Manag. 36, 115-129.

Lam, H.K., Zhan, Y., Zhang, M., Wang, Y., Lyons, A., 2019. The effect of supply chain finance initiatives on the market value of service providers. Int. J. Prod. Econ. 216, $227-238$.

Lamptey, L., Frimpong, K., Morrison, A., 2017. Empirical study on the influence of working capital management on performance of SMEs in a developing economy. British J. Econ. Manag. Trade 17 (4), 1-10.

Lanier, D., Wempe, W.F., Zacharia, Z.G., 2010. Concentrated supply chain membership and financial performance chain- and firm-level perspectives. J. Oper. Manag. 28 (1), $1-16$.

Laumann, E.O., Marsden, P.V., Prensky, D., 1983. The boundary specification problem in network analysis. In: Burt, R.S., Minor, M.J. (Eds.), Applied Network Analysis. Sage Publications, London, pp. 18-34.

Lazaridis, I., Tryfonidis, D., 2006. Relationship between working capital management and profitability of listed companies in the Athens stock exchange. J. Financ. Manag. Anal. 19 (1), 26-35.

Lee, T., Nam, H., 2016. An empirical study on the impact of individual and organizational supply chain orientation on supply chain management. Asian J. Shipp. Logist. 32 (4), 249-255.

Lorentz, H., Solakivi, T., Töyli, J., Ojala, L., 2016. Trade credit dynamics during the phases of the business cycle - a value chain perspective. Supply Chain Manag.: Int. J. 21 (3), 363-380.

Lyngstadaas, H., Berg, T., 2016. Working capital management: evidence from Norway. Int. J. Manag. Financ. 12 (3), 295-313.

Marak, Z., Pillai, D., 2019. Factors, outcome, and the solutions of supply chain finance: review and the future directions. J. Risk Financ. Manag. 12 (1), 3-26.

Martin, J., Hofmann, E., 2019. Towards a framework for supply chain finance for the supply side. J. Purch. Supply Manag. 25 (2), 157-171.

Mathuva, D.M., 2010. The influence of working capital management components on corporate profitability: a survey on Kenyan listed firms. Res. J. Bus. Manag. 4 (1), $1-11$.

Mello, J.E., Stank, T.P., 2005. Linking firm culture and orientation to supply chain success. Int. J. Phys. Distrib. Logist. Manag. 35 (8), 542-554.

Meltzer, A.H., 1960. Mercantile credit, monetary policy, and size of firms. Rev. Econ. Stat. 42 (4), 429-437.

Mentzer, J.T., DeWitt, W., Keebler, J.S., Min, S., Nix, N.W., Smith, C.D., Zacharia, Z.G., 2001. Defining supply chain management. J. Bus. Logist. 22 (2), 1-25.

Miia, P., 2014. The Cycle Times of Working Capital: Financial Value Chain Analysis Method. $\mathrm{PhD}$ Thesis. Lappeenranta University of Technology, Lappeenranta, Finland.

Monto, S., 2013. Towards Inter-organizational Working Capital Management. PhD Thesis. Lappeenranta University of Technology, Lappeenranta, Finland.

More, D., Basu, P., 2013. Challenges of supply chain finance: a detailed study and a hierarchical model based on the experiences of an Indian firm. Bus. Process Manag. J. 4, 624-647.

Moss, J.D., Stine, B., 1993. Cash conversion cycle and firm size: a study of retail firms. Manag. Financ. 19 (8), 25-34.

Moyen, N., 2004. Investment-cash flow sensitivities: constrained versus unconstrained firms. J. Financ. 59 (5), 2061-2092.

Mun, S.G., Jang, S., 2015. Working capital, cash holding, and profitability of restaurant firms. Int. J. Hosp. Manag. 48, 1-11.

Ng, C.K., Smith, J.K., Smith, R.L., 1999. Evidence on the determinants of credit terms used in interfirm trade. J. Financ. 54 (3), 1109-1129.

Nilsen, J.H., 2002. Trade credit and the bank lending channel. J. Money Credit Bank. 34 (1), 226-253.

Niskanen, J., Niskanen, M., 2006. The determinants of corporate trade credit policies in a bank-dominated financial environment: the case of Finnish small firms. Eur. Financ. Manag. 12 (1), 81-102.

Ogden, J.A., Petersen, K.J., Carter, J.R., Monczka, R.M., 2005. Supply management strategies for the future: a delphi study. J. Supply Chain Manag. 41 (3), 29-48.

Patatoukas, P.N., 2012. Customer-base concentration implications for firm performance 
and capital markets. Account. Rev. 87 (2), 363-392.

Petersen, M.A., Rajan, R.G., 1997. Trade credit: theories and evidence. Rev. Financ. Stud. 10 (3), 661-691.

Pfohl, H.-C., Gomm, M., 2009. Supply chain finance: optimizing financial flows in supply chains. Logist. Res. 1 (3-4), 149-161.

Pike, R., Neale, B., 2003. Corporate Finance and Investment: Decisions and Strategies, fourth ed. Financial Times Prentice Hall, Harlow.

Pohlen, T.L., Goldsby, T.J., 2003. VMI and SMI programs: how economic value added can help sell the change. Int. J. Phys. Distrib. Logist. Manag. 33 (7), 565-581.

Popa, V., 2013. The financial supply chain management: a new solution for supply chain resilience. Amfiteatru Econ. 15 (33), 140-153.

Protopappa-Sieke, M., Seifert, R., 2017. Benefits of working capital sharing in supply chains. J. Oper. Res. Soc. 68 (5), 521-532.

Rafuse, M.E., 1996. Working capital management: an urgent need to refocus. Manag. Decis. 34 (2), 59-63.

Raghavan, N.R.S., Mishra, V.K., 2011. Short-term financing in a cash-constrained supply chain. Int. J. Prod. Econ. 134 (2), 407-412.

Randall, W.S., Farris, T.M., 2009. Supply chain financing: using cash-to-cash variables to strengthen the supply chain. Int. J. Phys. Distrib. Logist. Manag. 39 (8), 669-689.

Ricci, C.W., Morrison, G., 1996. International working capital practices of the Fortune 200. Financ. Pract. Educ. 6 (2), 7-20.

Richards, V.D., Laughlin, E.J., 1980. A cash conversion cycle approach to liquidity analysis. Financ. Manag. 9 (1), 32-38.

Schwartz, R.A., 1974. An economic model of trade credit. J. Financ. Quant. Anal. 9 (4), 643-657.

Seifert, D., 2010. Collaborative Working Capital Management in Supply Networks. PhD Thesis. École Polytechnique Fédérale de Lausanne, Lausanne, Switzerland.

Serpa, J.C., Krishnan, H., 2018. The impact of supply chains on firm-level productivity. Manag. Sci. 64 (2), 511-532.

Shah, N.H., 2009. Optimisation of pricing and ordering under the two-stage credit policy for deteriorating items when the end demand is price and credit period sensitive. Int. J. Bus. Perform. Supply Chain Model. 1 (2), 229-239.

Sharma, A.K., Kumar, S., 2011. Effect of working capital management on firm profitability: empirical evidence from India. Glob. Bus. Rev. 12 (1), 159-173.

Shin, H.-H., Soenen, L., 1998. Efficiency of working capital management and corporate profitability. Financ. Pract. Educ. 8 (2), 37-45.

Shipley, D., Davies, L., 1991. The role and burden-allocation of credit in distribution channels. J. Mark. Channels 1 (1), 3-22.

Singh, H.P., Kumar, S., Colombage, S., 2017. Working capital management and firm profitability: a meta-analysis. Qualit. Res. Finan. Market. 9 (1), 34-47.
Singhania, M., Mehta, P., 2017. Working capital management and firms' profitability: evidence from emerging Asian countries. South Asian J. Business Stud. 6 (1), 80-97.

Smith, K.V., 1973. State of the art of working capital management. Financ. Manag. 2 (3), $50-55$.

Sousa, R., Voss, C.A., 2008. Contingency research in operations management practices. J. Oper. Manag. 26 (6), 697-713.

Soykan, M.E., Ulucak, R., 2016. Is there a non-linear relationship between net trade cycle and corporate performance in Turkey? Int. Bus. Res. 9 (6), 95-101.

Tauringana, V., Afrifa, G.A., 2013. The relative importance of working capital management and its components to SMEs' profitability. J. Small Bus. Enterp. Dev. 20 (3), 453-469.

Templar, S., Hofmann, E., Findlay, C., 2016. Financing the End-To-End Supply Chain: A Reference Guide to Supply Chain Finance, first ed. Kogan Page, London.

Tsai, C.-Y., 2008. On supply chain cash flow risks. Decis. Support Syst. 44 (4), 1031-1042.

Varadarajan, P.R., Jayachandran, S., White, J.C., 2001. Strategic interdependence in organizations deconglomeration and marketing strategy. J. Mark. 65 (1), 15-28.

Viskari, S., Kärri, T., 2012. A model for working capital management in the inter-organisational context. Int. J. Integr. Supply Manag. 7 (1-3), 61-79.

Walters, D., 2004. A business model for the new economy. Int. J. Phys. Distrib. Logist. Manag. 34 (3/4), 346-357.

Wang, Y.-J., 2002. Liquidity management, operating performance, and corporate value: evidence from Japan and Taiwan. J. Multinatl. Financ. Manag. 12 (2), 159-169.

Wichmann, B.K., Kaufmann, L., 2016. Social network analysis in supply chain management research. Int. J. Phys. Distrib. Logist. Manag. 46 (8), 740-762.

Wilner, B.S., 2000. The exploitation of relationships in financial distress: the case of trade credit. J. Financ. 55 (1), 153-178.

Wu, Y., Wang, Y., Xu, X., Chen, X., 2019. Collect payment early, late, or through a third party's reverse factoring in a supply chain. Int. J. Prod. Econ. 218, 245-259.

Wuttke, D.A., Blome, C., Foerstl, K., Henke, M., 2013a. Managing the innovation adoption of supply chain finance - empirical evidence from six European case studies. J. Bus. Logist. 34 (2), 148-166.

Wuttke, D.A., Blome, C., Heese, H.S., Protopappa-Sieke, M., 2016. Supply chain finance: optimal introduction and adoption decisions. Int. J. Prod. Econ. 178, 72-81.

Wuttke, D.A., Blome, C., Henke, M., 2013b. Focusing the financial flow of supply chains: an empirical investigation of financial supply chain management. Int. J. Prod. Econ. 145 (2), 773-789.

Zeidan, R., Shapir, O.M., 2017. Cash conversion cycle and value-enhancing operations: theory and evidence for a free lunch. J. Corp. Financ. 45, 203-219.

Zhang, T., Zhang, C.Y., Pei, Q., 2019. Misconception of providing supply chain finance: its stabilising role. Int. J. Prod. Econ. 213, 175-184. 